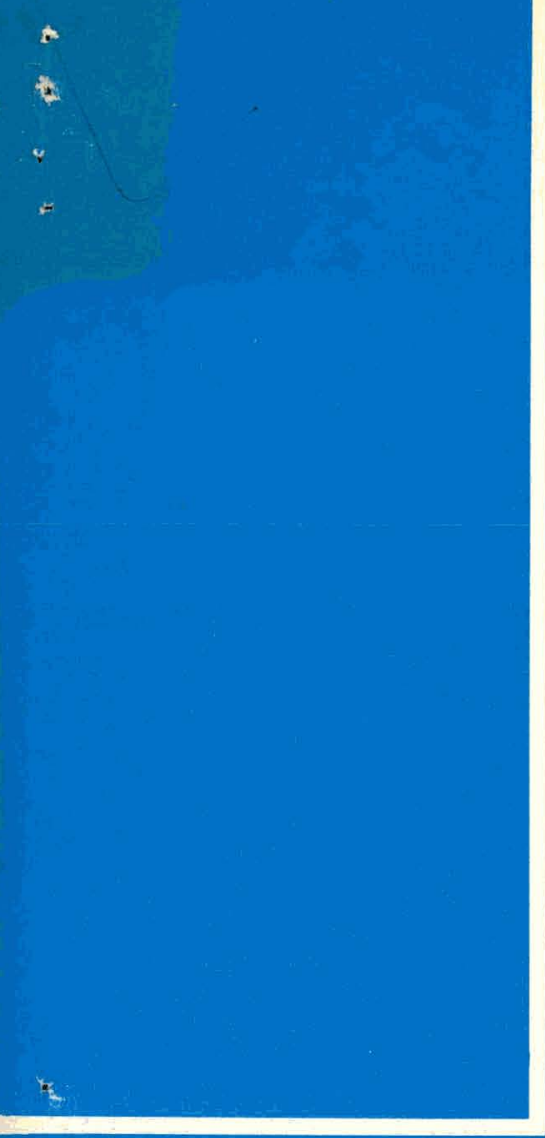

\title{
Safety Status of HTGR Structural Ceramics
}

\author{
G. C. Wei \\ J. R. DiStefano
}




\section{DISCLAIMER}

This report was prepared as an account of work sponsored by an agency of the United States Government. Neither the United States Government nor any agency Thereof, nor any of their employees, makes any warranty, express or implied, or assumes any legal liability or responsibility for the accuracy, completeness, or usefulness of any information, apparatus, product, or process disclosed, or represents that its use would not infringe privately owned rights. Reference herein to any specific commercial product, process, or service by trade name, trademark, manufacturer, or otherwise does not necessarily constitute or imply its endorsement, recommendation, or favoring by the United States Government or any agency thereof. The views and opinions of authors expressed herein do not necessarily state or reflect those of the United States Government or any agency thereof. 


\section{DISCLAIMER}

Portions of this document may be illegible in electronic image products. Images are produced from the best available original document. 


\section{Printed in the United States of America. Available trom}

National Technical Information Service

U.S. Department of Commerce

5285 Port Royal Road, Springfield, Virginia 22161

Price: Printed Copy $\$ 4.50$; Microfiche $\$ 3.00$

This report was prepared as an account of work sponsored by an agency of the United States Government. Neither the United States Government nor any agency thereof, nor any of their employees, contractors, subcontractors, or their employees, makes any warranty, express or implied, nor assumes any legal liability or responsibility for any third party's use or the results of such use of any information, apparatus, product or process disclosed in this report, nor represents that its use by such third party would not infringe privately owned rights. 
ORNL/TM-5680

Distribution category UC-77

Contract No. W-7405eng-26

OAK RIDGE NATIONAL LABORATORY

GAS-COOLED REACTOR PROGRAMS

\title{
SAFETY STATUS OF HTGR STRUCTURAL CERAMICS
}

G. C. Wei J. R. DiStefano

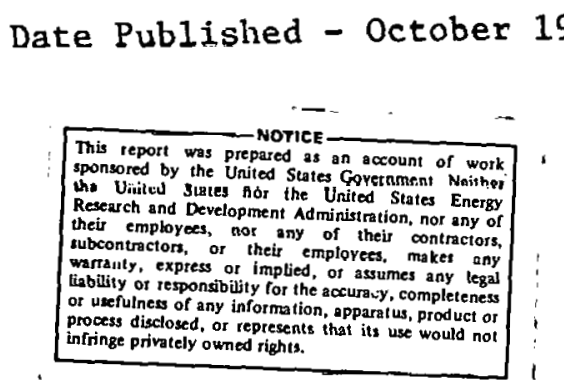

NOTICE This document contains information of a preliminary nature. It is subject to revision or correction and therefore does not represent a final report.

\author{
OAK RIDGE NATIONAL LABORATORY \\ Oak Ridge. Tennesse9 37830 \\ operated by \\ UNION CARBIDE CORPORATION \\ for the \\ DEPARTMENT OF ENERGY
}




\section{THIS PAGE}

\section{WAS INTENTIONALLY LEFT BLANK}




\section{CONTENTS}

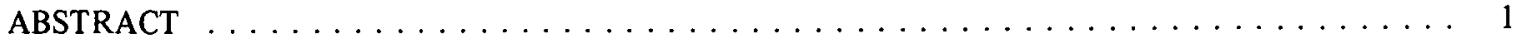

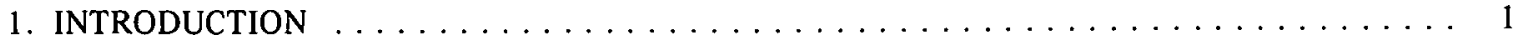

2. HTGR STRUCTURAL CERAMICS SYSTEM DESIGN, MATERIAL SELECTION, AND SAFETY PROBLEM AREAS $\ldots \ldots \ldots \ldots \ldots \ldots$

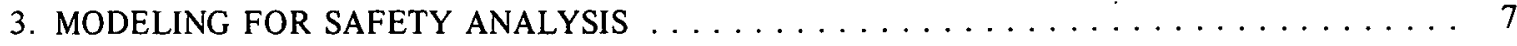

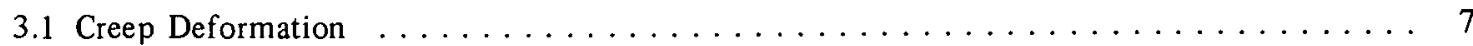

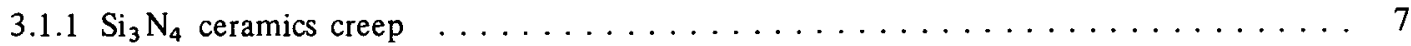

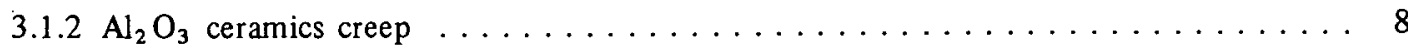

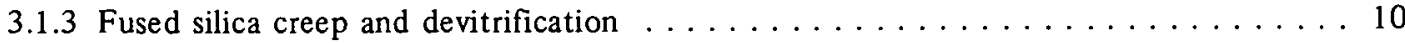

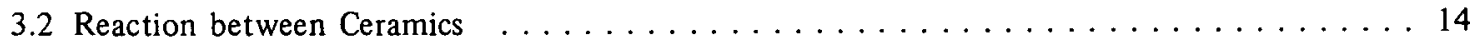

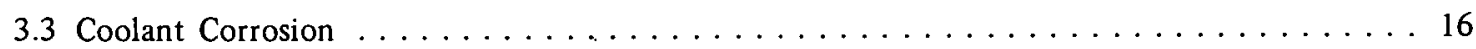

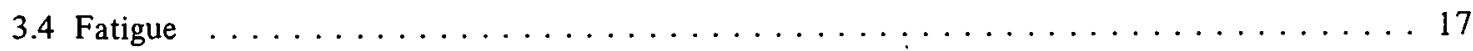

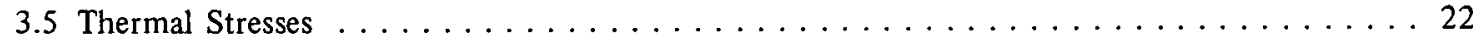

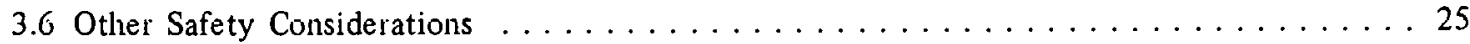

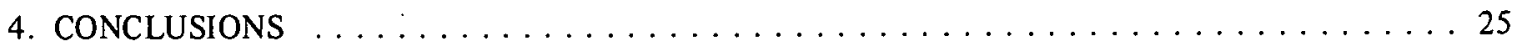




\title{
SAFETY STATUS OF HTGR STRUCTURAL CERAMICS
}

\author{
G. C. Wei J. R. DiStefano
}

\begin{abstract}
The objective of this study is to assess the safety status of structural ceramics proposed for use in an HTGR. In this report the mechanical and physical properties of the proposed structural ceramics are reviewed, and the current design and material specifications are discussed. Potential safety problem areas are identified.

Analytical models for creep deformation, devitrification, compatibility, fatigue, and thermal insulation stability are based on published work in the literature. The predictions made are generally based upon extrapolations to HTGR conditions.

The data indicate that creep deformation in silicon nitride and alumina ceramics is acceptable if the purity and composition are properly controlled. Devitrification and creep in fused silica used in the core support structure and the thermal barrier system could be excessive. Thermodynamic data indicate that silicon nitride will be incompatible with the graphite seat used in the design. Under normal reactor operating conditions, or during start-up and shutdown, static fatigue and thermal shock effects in all three members of the core support structural ceramics could cause reductions in safety factors.
\end{abstract}

\section{INTRODUCTION}

Structural ceramics in the core support system of a large high-temperature gas-cooled reactor (HTGR) have two important functions: (1) load bearing and (2) thermal insulation. The weight of the core is supported by graphite posts which rest on ceramic pads. The metal liners upon which the pads rest are protected from the high temperatures in the core primarily through the thermal insulation properties of the ceramic pads. Degradation in the load-bearing capabilities of the core support ceramics could lead to serious accidents such as collapse of the structural ceramics. Safe operation of an HTGR depends critically upon the performance of these structural ceramics.

The current design employs a three-layer composite consisting of a silicon nitride upper pad in contact with the graphite seat, an alumina middle pad, and a silica lower pad in contact with the metal liner. This system design and selection of materials are, however, only tentative because there are few commercially available materials that can simultaneously meet the requirement of long-term stability in terms of mechanical strength, compatibility, and thermal insulation.

This report constitutes an analytical study of the proposed core support ceramics from the safety viewpoint. Mechanical properties, thermal insulation properties, and compatibility are evaluated. In some cases, extrapolation or interpolation of the reported literature data was necessary because the stress, temperature, and atmospheric conditions for HTGR structural ceramics are not within the range of the reported literature studies. A model for safety analysis in terms of creep, fatigue, and crystallization in HTGR structural ceramics was developed for predicting the behavior of currently proposed materials and investigating problems related to safety. 


\section{HTGR STRUCTURAL CERAMICS SYSTEM DESIGN, MATERIAL SELECTION, AND SAFETY PROBLEM AREAS}

In an HTGR, graphite is used in the active core assembly, bottom reflector, core support block, post, and post seat. Each graphite core support block is supported by three graphite posts resting on ceramic disks supported by the metal liners of the prestressed concrete reactor vessel. The principal candidate ceramics for these structural support and thermal barrier applications are silicon nitride, alumina, and fused silica. A schematic of the HTGR structural ceramic support system is shown in Fig. 1.

The design load on the ceramic pads is $9091 \mathrm{~kg}(20,000 \mathrm{lb})$ under normal operating conditions. Under operational basis earthquake and safe shutdown earthquake conditions, the loads are $12,273 \mathrm{~kg}(27,000 \mathrm{lb})$ and $14,545 \mathrm{~kg}(32,000 \mathrm{lb})$ respectively. Lateral movement of the load above the ceramic pads can cause an additional $227 \mathrm{~kg}(500 \mathrm{lb})$ of force. Possible seismic events will introduce small tensile or compressive stresses in the ceramic pads. Loading cycles due to such events and other incidents will have amplitudes of about $6.895 \times 10^{5} \mathrm{~Pa}(100 \mathrm{psi})$, and the frequency is expected to be about 100 times in 40 years. The pads are supposed to withstand a compressive load of approximately $22,727 \mathrm{~kg}(50,000 \mathrm{lb})$ at a hot-face temperature of $1093^{\circ} \mathrm{C}\left(2000^{\circ} \mathrm{F}\right)$ with a creep strain of less than $2 \%$ at the end of the service life. ${ }^{1}$ Grafoil $^{2}$ is used between the pads for better load distribution, namely, to reduce effects of any stress concentrators which can cause longitudinal cracking. The structural ceramics are surrounded by thermal barriers consisting of fused silica at the silicon nitride pad and graphite post seat, and fibrous insulation materials such as Kaowool ${ }^{3}$ blanket at the alumina and fused-silica pads.

1. "Component and Systems Development Program," pp. 2-6 in GA-A UC-77 Q. Prog. Rep. June 30, 1976.

2. Product of Union Carbide Corp., New York, N.Y.

3. Product of Babcock and Wilcox, Augusta, Ga.

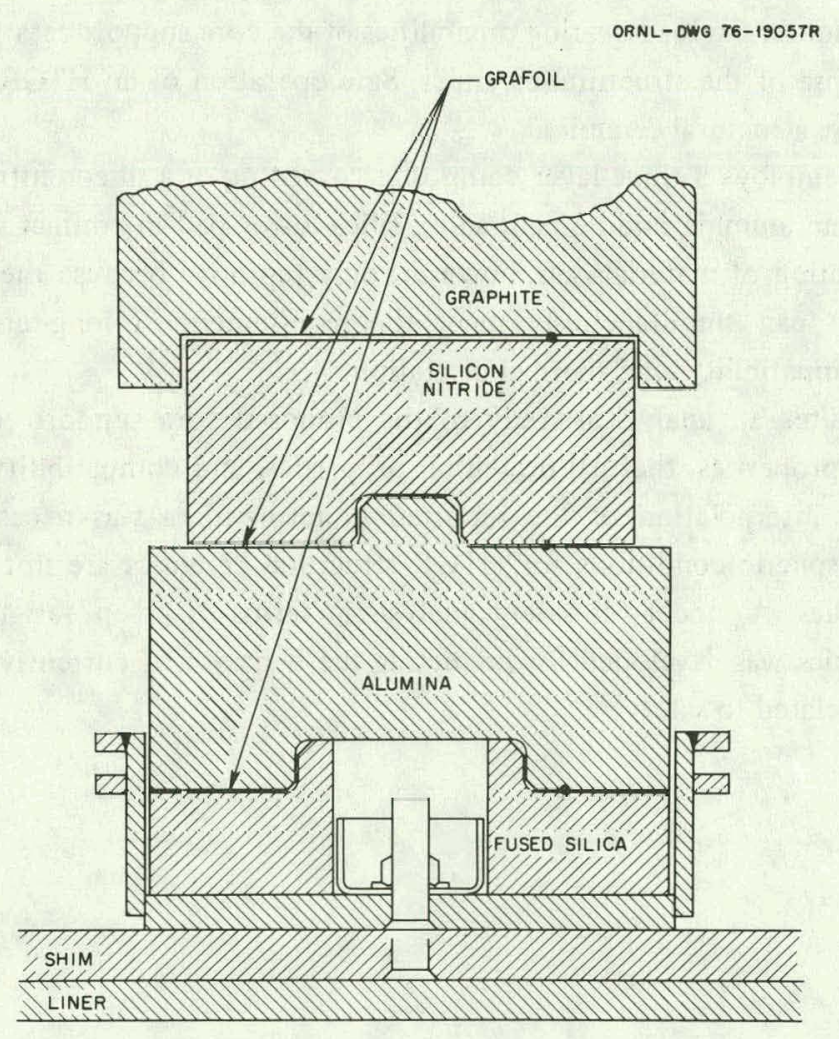

Fig. 1. Schematic of the HTGR structural ceramics system. 
Under normal conditions, the volume-average temperatures for the three ceramic pads are 816,735 , and $529^{\circ} \mathrm{C}\left(1500,1355\right.$, and $\left.985^{\circ} \mathrm{F}\right)$ respectively. For a significant fraction of the service life $(25 \%)$, the operating temperatures for the three are 902,810 , and $574^{\circ} \mathrm{C}\left(1655,1490\right.$, and $\left.1065^{\circ} \mathrm{F}\right)$. The steepest temperature gradient occurs in the fused-silica pad due to its relatively low thermal conductivity. Thermal stresses are generated by this type of temperature gradient in both the longitudinal and the radial directions, and by the temperature gradient due to transient thermal cycling.

Helium gas is the HTGR primary coolant. Impurities in the helium under various conditions are shown in Table 1. The effect of these impurities on the properties of the ceramic materials should be determined. Under certain conditions, species such as $\mathrm{H}_{2} \mathrm{O}, \mathrm{CO}$, and $\mathrm{H}_{2}$ can react with the ceramics and cause degradation in the load-bearing and/or thermal insulation properties.

Another factor that should be considered is the effect of radiation on these materials. The neutron irradiation fluence in the structural ceramics will be on the order of $10^{17}$ (fast neutron), $10^{18}$ (intermediate-energy neutron), and $10^{20}$ (thermal neutron) neutrons $/ \mathrm{cm}^{2}$.

The proposed ceramic materials are commercially available in various' qualities and grades, many of which are poorly defined. Magnesia-doped silicon nitride hot pressed to full density normally has an impurity content as listed in Table 2, which shows the impurities in two different types of hot-pressed

Table 1. Impurity concentrations in HTGR helium coolant under three conditions

\begin{tabular}{lccr}
\hline \multirow{2}{*}{ Impurity } & \multicolumn{3}{c}{ Partial pressure $\left(10^{-6} \mathrm{~atm}\right)$} \\
\cline { 2 - 4 } & Case $1^{a}$ & Case $2^{b}$ & Case $3^{c}$ \\
\hline $\mathrm{H}_{2} \mathrm{O}$ & $<1$ & 50 & 200 \\
$\mathrm{CH}_{4}$ & 20 & 50 & 100 \\
$\mathrm{CO}_{2}$ & $<1$ & $\leq 2$ & 5 \\
$\mathrm{H}_{2}$ & $\left(\mathrm{H}_{2} / \mathrm{H}_{2} \mathrm{O}\right.$ ratio $\left.\geq 1000 / 1\right)$ & 1500 & 3000 \\
$\mathrm{CO}_{\mathrm{O}}$ & 10 & 450 & 800 \\
\hline
\end{tabular}

${ }^{a}$ Normal condition in the Peach Bottom Reactor.

${ }^{b}$ Maximum continuous condition.

Immediale sliutdown oondition.

Source: O. F. Kimball and D. I. Roberts, Survey of Materiuls Data Necds for HTGR, GA-A13354 (April 1975).

Table 2. Impurities obscrved in three commercial types of silicon nitride

\begin{tabular}{|c|c|c|c|c|c|c|c|c|c|c|c|c|c|}
\hline \multirow{2}{*}{ Product } & \multicolumn{13}{|c|}{ Elemental concentration (wt \%) } \\
\hline & Al & B & $\mathrm{Ca}$ & C. & $\mathrm{Fe}$ & $\mathrm{K}$ & $\mathrm{Mg}$ & $\mathrm{Mn}$ & $\mathbf{N a}$ & $\mathrm{Ni}$ & $\mathbf{T i}$ & $\mathbf{W}$ & $\mathrm{C}$ \\
\hline HS- $110^{a}$ & 0.8 & 0.01 & 0.5 & 0.2 & 0.6 & 0.01 & 0.6 & 0.02 & 0.01 & 0.01 & 0.01 & $\sim 3$ & 0.41 \\
\hline HS- $130^{\alpha}$ & $\begin{array}{l}0.07- \\
0.12\end{array}$ & 0.001 & $\begin{array}{l}0.02 \\
0.08\end{array}$ & 0.04 & $\begin{array}{l}0.7- \\
0.1\end{array}$ & $\begin{array}{l}0.004- \\
0.007\end{array}$ & 0.7 & 0.04 & $\begin{array}{l}0.003- \\
0.02\end{array}$ & 0.01 & 0.02 & $\begin{array}{l}0.3- \\
3\end{array}$ & $\begin{array}{l}0.43- \\
0.04\end{array}$ \\
\hline Ceralloy $147 A^{b}$ & 0.4 & 0.003 & 0.3 & 0.1 & 1.0 & 0.001 & $>1$ & 0.06 & 0.02 & 0.05 & .0 .03 & NA & NA \\
\hline
\end{tabular}

${ }^{a_{\text {Product }}}$ of Norton Co., Worcester, Mass. Data taken from R. Kossowsky, "The Microstructure of Hot-Pressed Silicon Nitride," J. Mater.' Sci. 8, 1603-15 (1973).

${ }^{b}$ Product of Ceradyne, Inc., Santa Ana, Calif. Data are analysis of puwder feed before hot pressing. 
$\mathrm{Si}_{3} \mathrm{~N}_{4}$. Note that both the Norton (HS1 $10^{4}$ or $\mathrm{HS} 30^{4}$ ) and Ceradyne (Ceralloy $147 \mathrm{~A}^{5}$ ) silicon nitrides show appreciable amounts of impurities such as $\mathrm{Mg}, \mathrm{Fe}, \mathrm{Ca}, \mathrm{Na}$, and $\mathrm{Si}$. Dense alumina ceramics are generally fabricated by sintering, or sometimes by hot pressing. Two types of alumina ceramics under consideration for use in the column typically have impurity contents as shown in Table 3 . The major impurities are $\mathrm{Si}, \mathrm{Ca}, \mathrm{Mg}$, and $\mathrm{Na}$. One type of fused silica being considered for use has the impurity specifications shown in Table 4. The major impurities are $\mathrm{OH}, \mathrm{Al}, \mathrm{Ca}, \mathrm{Fe}$, and $\mathrm{Na}$ plus $\mathrm{K}$. According to the manufacturer, the crystalline phases in this fused-silica product constitute $0.5 \%$ by volume. Fused silica is commercially available in many different forms and qualities. Some are of higher purity, in terms of hydroxyl ion and metallic impurity content, than the candidate material presently considered.

In addition to the materials discussed above, other oxide or carbide ceramics are also potential candidates for the HTGR structural ceramics application. These include thoria $\left(\mathrm{ThO}_{2}\right)$, silicon carbide, stabilized zirconia, and graphite. There is some evidence that silicon nitrido may be incompatible will lle graphite seat. The decomposition of silicon nitride in the presence of carbon and the formation of silicon carbide may require use of other ceramics to replace silicon nitride. It is also worth while to note that the current design consists of a three-layer, composite ceramic system instead of a simple one-material system because no single ceramic material can simultaneously withstand a compressive stress of about $3.45 \mathrm{MPa}$ (500 psi) at a hot-face temperature of $900^{\circ} \mathrm{C}\left(1652^{\circ} \mathrm{F}\right)$ and a cold-face temperature of $64^{\circ} \mathrm{C}\left(148^{\circ} \mathrm{F}\right)$ across the available total pad height for 40 years.

The particular physical and mechanical properties of the proposed materials of concern from the safety point of view are compressive strength, thermal conductivity, creep rate, density, heat capacity, thermal conductivity, linear thermal expansion coefficient, and elastic modulus. The variance of these properties

4. Product of Norton Co., Worcester, Mass.

5. Producl ur Ceradyne, Inc., Santa Ana, Calif.

Talys 3. Inpurlites in two types of commercial alumina ceramics

\begin{tabular}{lcc}
\hline \multirow{2}{*}{ Component } & \multicolumn{2}{c}{ Weight percent } \\
\cline { 2 - 3 } & $\mathrm{AD}-995^{a}$ & Ceralloy $138^{b}$ \\
\hline $\mathrm{SiO}_{2}$ & 0.15 & \\
$\mathrm{Fe}_{2} \mathrm{O}_{3}$ & 0.03 & \\
$\mathrm{CaO}$ & 0.13 & \\
$\mathrm{MgO}$ & 0.10 & \\
$\mathrm{Na}, \mathrm{O}$ & 0.5 & \\
$\mathrm{Si}$ & & 0.05 \\
$\mathrm{l} \mathrm{c}$ & & 0.03 \\
$\mathrm{Ca}$ & & 0.04 \\
$\mathrm{Mg}$ & & 0.002 \\
$\mathrm{Na}$ & & 0.03 \\
$\mathrm{~Pb}$ & & $<0.001$ \\
$\mathrm{P}$ & & 0.3 \\
\hline
\end{tabular}

${ }^{a}$ Product of Coors Porcelain Co., Golden, Colo. Data are chemical analysis on sintered product in oxide equivalents.

${ }^{b}$ Product of Ceradyne, Inc., Santa Ana, Calif. Data are chemical analysis of powder feed before hot pressing. 
Table 4. Chemical composition of standard Masrock ${ }^{a}$ in oxide equivalents

\begin{tabular}{lc}
\hline \multicolumn{1}{c}{ Species } & Content \\
\hline $\mathrm{SiO}_{2}$ & $99.6 \mathrm{wt} \%$ \\
$\mathrm{Al}_{2} \mathrm{O}_{3}$ & $0.2 \mathrm{wt} \%$ \\
$\mathrm{Fe}_{2} \mathrm{O}_{3}$ & $0.03 \mathrm{wt} \%$ \\
$\mathrm{CaO}+\mathrm{MgO}$ & $0.03 \mathrm{wt} \%$ \\
$\mathrm{Na}_{2} \mathrm{O}+\mathrm{K}_{2} \mathrm{O}$ & $0.02 \mathrm{wt} \%$ \\
$\mathrm{P}_{2} \mathrm{O}_{5}$ & $0.2 \mathrm{wt} \%$ \\
$\mathrm{FeO}_{\mathrm{TiO}}$ & $600 \mathrm{ppm}$ \\
$\mathrm{H}_{2} \mathrm{O}$ & $200 \mathrm{ppm}$ \\
\hline
\end{tabular}

${ }^{a}$ Product of Glasrock Products, Inc., Atlanta, Ga.

from the manufacturer's data may be significant, and little is known concerning property variations in sections of the size required for this application. Some reported data from company sources and the open literature are presented in Table 5. As reported by the manufacturers, the values for these properties vary with the method of manufacture and the size and shape of the specimen. This is because the properties of ceramics depend greatly on the raw material, the fabrication technique, the resultant microstructure, and the finishing. Slight variations in the impurity species and contents in different batches of raw material and differences in the densification process and machining and surface polishing processes will yield a broad range of product properties, especially where mechanical properties are concerned. Even at temperatures up to the melting point, mechanical or physical properties of ceramics are generally dominated by such extrinsic factors.

From the safety view, HTGR structural ceramics need long-term structural and thermal insulation stability. Compressive creep rates at operational temperatures and stresses should be extremely low. The total creep strain over a service life of 40 years is desired to be less than $2 \%$. In order to accurately predict the behavior of these materials, the effect of structural and microstructural changes should be considered. Grain growth and crack growth in all three ceramic components could enhance the creep rate and reduce the compressive strength and the thermal insulation properties. A significant loss in compressive strength of the structural support ceramics would reduce the safety factor and thus increase the probability of a structural failure in the core support system. In addition, excess deformation will result in a smaller total insulation thickness and thus increase the cold-surface temperature.

Instability in the thermal insulation properties of the structural ceramics is also of significant safety concern. If the thermal conductivity increases significantly, for example, due to devitrification in the fused silica, a reaction between ceramic pads, or impurity diffusion out of the ceramics, the cold face of the structural ceramics could become rather hot.

Fatigue failure due to constant load, thermal cycling, or load cycling in a corrosive environment containing species such as $\mathrm{H}_{2} \mathrm{O}, \mathrm{CO}$, and $\mathrm{H}_{2}$ is another potential material problem of safety concern. Fatigue (or stress corrosion) can result in degradation in load-bearing and thermal insulation capabilities of the materials.

Finally, thermal shock effects in the structural ceramics during start-up, shutdown, and, especially, emergency shutdown operation need to be analyzed, since an HTGR is inherently a higher-temperature facility than current commercial nuclear fission reactors and imposes a significant degree of thermal stress on the structural ceramics and the surrounding thermal barrier system in the heat-up and cool-down portions of the reactor operating cycle. 
Table 5. Reported properties of proposed HTGR structural ceramics

\begin{tabular}{|c|c|c|c|c|c|c|c|}
\hline Property & $\begin{array}{l}\mathrm{AD}-99, a \\
\mathrm{Al}_{2} \mathrm{O}_{3}\end{array}$ & $\begin{array}{c}\mathrm{AD}-999^{a}, \\
\mathrm{Al}_{2} \mathrm{O}_{3}\end{array}$ & $\begin{array}{l}\text { Ceralloy } 138, b \\
\mathrm{Al}_{2} \mathrm{O}_{3}\end{array}$ & $\begin{array}{c}\text { Ceralloy } 147 \mathrm{~A}, b \\
\mathrm{Si}_{3} \mathrm{~N}_{4}\end{array}$ & $\begin{array}{l}\text { Masrock, }{ }^{c} \\
\mathrm{SiO}_{2}\end{array}$ & $\begin{array}{c}\text { Hi-Purity } \\
\text { fused, silica, } \\
\mathrm{SiO}_{2}\end{array}$ & $\begin{array}{c}\text { Ceralloy } 908 \mathrm{C}, b \\
\mathrm{ThO}_{2}\end{array}$ \\
\hline $\begin{array}{l}\text { Specific gravity, } \\
\mathrm{g} / \mathrm{cm}^{3}\end{array}$ & 3.83 & 3.96 & 3.89 & 3.11 & $1.76-1.89$ & 1.95 & .9 .75 \\
\hline $\begin{array}{l}\text { Compressive strength, } \\
\text { psi }\end{array}$ & $30 \mathrm{C}: 00 \mathrm{C}$ & 550,000 & $3 \mathrm{C} 0,000-500,000$ & $300,000-500,000$ & $10,000-23,000$ & 20,000 & $200,000-400,000$ \\
\hline $\begin{array}{l}\text { Modulus of } \\
\text { elasticity, psi } \\
\left(25^{\circ} \mathrm{C}\right)\end{array}$ & $50 \times 10^{-}$ & $56 \times 10^{6}$ & $50-60 \times 10^{6}$ & $41-45 \times 10^{6}$ & & & $30-40 \times 10^{6}$ \\
\hline $\begin{array}{l}\text { Specific heat, } \\
\text { Btu/lb. }{ }^{\circ} \mathrm{F} \\
\left(100^{\circ} \mathrm{C}\right)\end{array}$ & 0.21 & 0.21 & & & & & \\
\hline $\begin{array}{l}\text { Thermal conductivity, } \\
\text { Btu.in./ } \mathrm{ft}^{2} \cdot \text { hr } .^{\circ} F\end{array}$ & $\begin{array}{l}204\left(25^{\circ} \mathrm{C}\right) \\
\left.160(101)^{\circ} \mathrm{C}\right)\end{array}$ & $\begin{array}{l}216\left(25^{\circ} \mathrm{C}\right) \\
160\left(100^{\circ} \mathrm{C}\right)\end{array}$ & $228-300\left(25-100^{\circ} \mathrm{C}\right)$ & $72-120\left(25-100^{\circ} \mathrm{C}\right)$ & $\begin{array}{l}2.3\left(150^{\circ} \mathrm{C}\right) \\
7.8\left(1100^{\circ} \mathrm{C}\right.\end{array}$ & $7.5\left(550^{\circ} \mathrm{C}\right)$ & $6-8\left(25-1000^{\circ} \mathrm{C}\right)$ \\
\hline $\begin{array}{l}\text { Linear thermal } \\
\text { expansion } \\
\text { coefficient, } \\
10^{-6} /{ }^{\circ} \mathrm{C}\end{array}$ & $8.2\left(25-1000^{\circ} \mathrm{C}\right)$ & $8.0\left(25-1000^{\circ} \mathrm{C}\right)$ & $8.0\left(25-1000^{\circ} \mathrm{C}\right)$ & $3.0\left(25-1000^{\circ} \mathrm{C}\right)$ & $0.7\left(0-1000^{\circ} \mathrm{C}\right)$ & $3\left(25-1100^{\circ} \mathrm{C}\right)$ & $9.3\left(25-1000^{\circ} \mathrm{C}\right)$ \\
\hline
\end{tabular}

${ }^{a}$ Product of Coors Porcelain Co., Golden, Colo.

$b_{\text {Product }}$ Ceradyne. Inc., Santa Ana, Cälif.

${ }^{c}$ Product of Glasrock Products, Inc., Atlarta, Ga. 


\section{MODELING FOR SAFETY ANALYSIS}

\subsection{Creep Deformation}

3.1.1 $\mathrm{Si}_{3} \mathrm{~N}_{4}$ ceramics creep. Commercial-grade hot-pressed $\mathrm{Si}_{3} \mathrm{~N}_{4}$ usually contains about 0.3 wt $\% \mathrm{MgO}$ or $\mathrm{Y}_{2} \mathrm{O}_{3}$ added to improve densification. Evidence suggests that these oxides form liquid phases at high temperature and thereby enhance densification by a solution-reprecipitation mechanism. ${ }^{6}$ It appears that $\alpha-\mathrm{Si}_{3} \mathrm{~N}_{4}$ powders are needed to fabricate $\mathrm{Si}_{3} \mathrm{~N}_{4}$ that has high strength at high temperatures. ${ }^{7}$ Microstructural examination of commercial-grade $\mathrm{Si}_{3} \mathrm{~N}_{4}$ has revealed some nondensified $\mathrm{Si}_{3} \mathrm{~N}_{4}$ particles. ${ }^{8}$ These inclusions are essentially flaws which can cause a substantial decrease in strength under certain stress conditions. At $1200-1400^{\circ} \mathrm{C}\left(2192-2552^{\circ} \mathrm{F}\right)$ it has been reported that creep in $\mathrm{Si}_{3} \mathrm{~N}_{4}$ is due to grainboundary sliding accommodated by deformation al triple points and by limited local plastic deformation rather than plastic flow within the crystallites. ${ }^{9}$ At high temperatures, the amorphous grain-boundary phase becomes less viscous, so that grains start to separate and slide under stress. This sliding and separation is most pronounced at the tips of preexisting cracks, which are the most highly stressed portions of the material. Under a condition of constant load, internal flaws can slowly grow until they reach a critical size that will cause sudden catastrophic failure. The high-temperature compressive strength and creep resistance of hot-pressed $\mathrm{Si}_{3} \mathrm{~N}_{4}$ can be significantly improved by upgrading the chemistry of the grain-boundary phase. An impurity compound containing calcium, sodium, potassium, silicon, and oxygen, which is concentrated in the boundary phase, strongly influences the high-temperature mechanical properties of this material. It is thus desirable to have high-purity starting powder and a hot-pressing aid with a critically controlled composition. The improvement in the creep resistance using such control can be as much as three orders of magnitude. ${ }^{6}$

Recently, extensive investigations of $\mathrm{Si}_{3} \mathrm{~N}_{4}$ by Westinghouse Corporation workers have provided much information on mechanical properties. ${ }^{10}$ The steady-state tensile creep rates at $1260^{\circ} \mathrm{C}\left(2300^{\circ} \mathrm{F}\right)$ in air for improved $\mathrm{Si}_{3} \mathrm{~N}_{4}$ hot pressed with $\mathrm{MgO}$ are about $2.5 \times 10^{-6}$ in. in. ${ }^{-1} \mathrm{hr}^{-1}$ for $103.4 \mathrm{MPa}(15,000 \mathrm{psi})$ and about $1.4 \times 10^{-5}$ in. in. ${ }^{-1} \mathrm{hr}^{-1}$ for $172.4 \mathrm{MPa}(25,000 \mathrm{psi}) .^{6}$ Much smaller creep rates occur in compression under similar conditions. Depending on details of the measurement, compressive strengths of ceramics are 5 to 20 times as great as tensile strengths. Nicholson et al. measured the steady-state creep rate of Norton $\mathrm{Si}_{3} \mathrm{~N}_{4}$ (HS 130) and found that the creep rate was proportional to stress to about the 1.7 power. ${ }^{9}$ An activation energy of $140 \mathrm{kcal} / \mathrm{moe}$ was observed. Their data can be described by

$$
\dot{\epsilon}=7.4 \times 10^{7} \exp (-140,000 / R T) \sigma^{1.7},
$$

where $\dot{\epsilon}$ is the creep rate (in. in. ${ }^{-1} \mathrm{hr}^{-1}$ ), $\sigma$ is the stress (psi), and $R T$ has the usual meaning.

No analytical description for the creep process in $\mathrm{Si}_{3} \mathrm{~N}_{4}$ ceramics is available in terms of fundamental parameters. However, creep deformation in silicon nitride can be estimated from Nicholson's data. At $T=$ $900^{\circ} \mathrm{C}\left(1652^{\circ} \mathrm{F}\right)$ and $\sigma=6.895 \mathrm{MPa}(1000 \mathrm{psi})$ (which is close to the typical condition experienced by $\mathrm{Si}_{3} \mathrm{~N}_{4}$ in the HTGR core support system), the resultant strain is very small $\left(7.6 \times 10^{-14}\right.$ in. in. $\left.{ }^{-1} \mathrm{hr}^{-1}\right)$. At this creep rate, the total creep strain over 40 years is only $2.7 \times 10^{-6} \%$. The extremely small amount of

6. F. F. Lange, "Structural Ceramic Materials under Development," ASME Gas Turbine Conference, Houston, Tex., March 2-6, 1975.

7. F. F. Lange, "Relation between Strength, Fracture Energy, and Microstructure of Hot-Pressed $\mathrm{Si}_{3} \mathrm{~N}_{4}, " J . A m$. Ceram. Soc. 56(10), 518-22 (1973).

8. R. Kossowsky, "The Microstructure of Hot-Pressed Silicon-Nitride," J. Mater. Sci. 8, 1603-15 (1973).

9. S. U. Din and P. S. Nicholson, "Creep of Hot-Pressed Silicon Nitride," J. Mater. Sci. 10, 1375-80 (1975).

10. R. J. Bratton et al., Brittle Materials Design, High Temperature Gas Turbine, AMMRC CTR 75-8 (April 1975). 
creep strain suggests that, as far as creep deformation is concerned, $\mathrm{Si}_{3} \mathrm{~N}_{4}$ is satisfactory for the HTGR application if the grain-boundary chemistry is properly controlled.

3.1.2 $\mathrm{Al}_{2} \mathrm{O}_{3}$ ceramics creep. Analysis of the creep data for $\mathrm{Al}_{2} \mathrm{O}_{3}$ indicates that at low stresses, creep is controlled by diffusion. ${ }^{11}$ At stresses approaching the nonbasal yield stresses $\left(10^{-2}\right.$ to $10^{-3}$ times the shear modulus), slip will contribute appreciably to deformation of polycrystalline alumina ceramics. For mediumand fine-grained materials (grain size less than $60 \mu \mathrm{m}$ ), diffusional creep involves mass transport between grain boundaries. For larger grain sizes, the Nabarro climb mechanism ${ }^{12}$ becomes the dominant creep process. Grain-boundary sliding is necessary to maintain material integrity during steady-state diffusional creep, but normally it does not limit the creep rate. In steady-state creep, diffusion between small steps along the boundaries will also not be rate-limiting. While diffusion is identified as the mechanism for the creep phenomenon in $\mathrm{Al}_{2} \mathrm{O}_{3}$ ceramics, it is still undetermined as to which species is rate-controlling. There is evidence suggesting that diffusion of oxygen along grain boundaries is fast enough so that at moderate grain sizes, creep is controlled by the relatively slower aluminum ion lattice diffusion, which is enhanced by doping with multivalent cation impurities. For very fine-grained alumina ceramics, creep is controlled by cation boundary diffusion. ${ }^{11}$ At coarse grain sizes, oxygen boundary diffusion will be limiting.

In alumina ceramics that contain a second phase, deformation will be determined by the relative ease of deformation in both the primary corundum phase and the second phase. Commercially available alumina ceramics usually contain significant amounts of silica, which forms a glassy phase in the presence of small amounts of alkali metal oxides. Creep deformation in this type of alumina is controlled by the amount of glassy phase, because mass transport for creep is usually faster in this phase than in the alumina phase. The composition of the glassy secondary phase differs from sample to sample, depending on the original batch constituents. One example is shown in Fig. 2. This is the microstructure of a commercial alumina ceramic,

11. R. M. Cannon, "Diffusional Creep in Alumina," Sc.D. thesis, Department of Materials Science and Engineering, MIT, May 1975.

12. F. R. N. Nabarro and C. Herring, J. Appl. Phys. 21, 437 (1950).

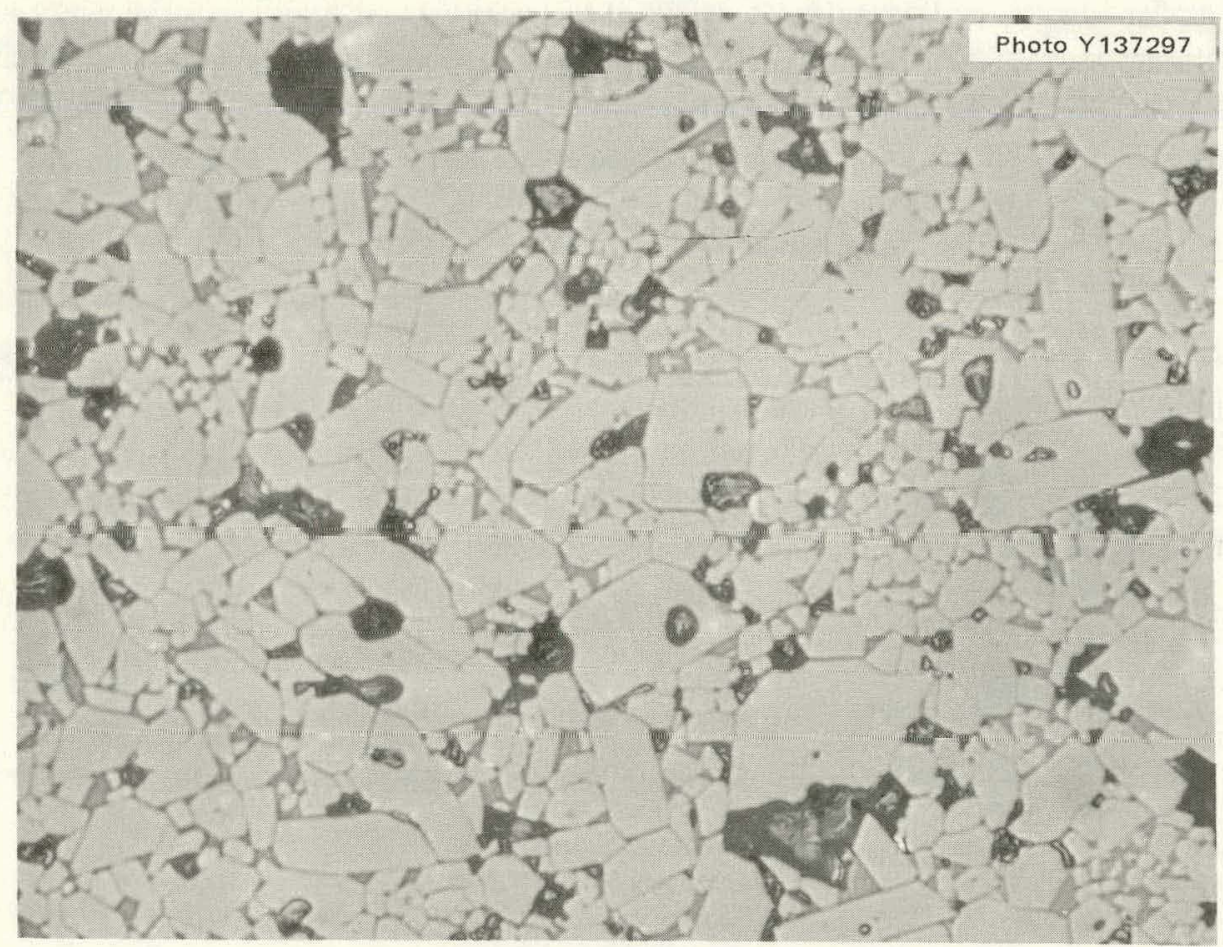

Fig. 2. Microstructure of AD-94 alumina ceramic. The gray area is a glassy phase, and the dark areas are pores. $500 \times$. 
AD-94. ${ }^{13}$ The visible gray material represents the glassy phase in this figure. Very pure alumina (over 99.9\%) can of course be a single-phase material. Creep in this type of ceramic involves mass transport through point defects, which are normally controlled by impurities up to the melting point. Because the native aliovalent impurity content can differ appreciably from sample to sample, the steady-state creep rate varies, and widely scattered experimental data are found. In modeling creep in very pure alumina ceramics, two analytical expressions are proposed in the literature, depending on the range of grain size. For finegrained alumina, the Coble model is applicable: ${ }^{14}$

$$
\dot{\epsilon}=47.1 \frac{W D_{B} \Omega}{K T} \cdot \frac{\sigma}{G^{3}}\left(1-p^{2 / 3}\right)^{-1}
$$

where $W$ is the grain-boundary width, $D_{B}$ is the grain-boundary diffusivity, $G$ is the grain size, $p$ is the volume fraction of the porosity, $\Omega$ is the atomic volume of the diffusing species, and $\dot{\epsilon}$ is the creep rate.

For large-grain-size alumina, the Nabarro-Herring expression is applicable: ${ }^{12}$

$$
\dot{\epsilon}=\frac{40 D_{L} \Omega}{3 K T} \cdot \frac{\sigma}{G^{2}}\left(1-p^{2 / 3}\right)^{-1}
$$

where $D_{L}$ is the lattice diffusivity and the other terms have the same definitions as given for Eq. (2).

During the HTGR service life, several parameters in these analytical expressions can change appreciably. For instance, grains may grow, porosity may decrease, and diffusivity may increase or decrease due to thermally induced migration of impurities. If grain growth occurs, the creep rate will be reduced, because in the Coble model and the Nabarro-Herring model the creep rates are inversely proportional to the square and the cube of the grain size respectively. Grain growth during service is, therefore, favorable in terms of creep. The problem caused by grain growth, if any, is perhaps a reduction in the compressive strength and thermal shock resistance. The compressive strength of ceramics is generally inversely proportional to the square root of the grain size. According to an early study by Coble, the isothermal grain growth in alumina can be expressed by an empirical expression, ${ }^{15}$

$$
G=G_{0}+k t^{3}
$$

where $G_{0}$ is the initial grain size, $k$ is a constant $\left[k \cong 2.7 \times 10^{-22} \mu \mathrm{m} / \mathrm{min}^{3}\right.$ at $800^{\circ} \mathrm{C}\left(1472^{\circ} \mathrm{F}\right)$, by extrapolation], and $t$ is the time in minutes. Equation (4) predicts an increase of about $2 \mu \mathrm{m}$ in the grain size at the end of 40 years at a temperature of $800^{\circ} \mathrm{C}\left(1472^{\circ} \mathrm{F}\right)$. Assuming a starting grain size of $2 \mu \mathrm{m}$, this would probably decrease the compressive strength by about 30\%; however, an anticipated reduction in porosity will probably offset this effect. Under load, alumina in the HTGR structural support application is essentially undergoing a hot-pressing process. The porosity will be reduced, and therefore the compressive strength will increase. Diffusivity changes due to impurity migration are believed to be a minor effect.

In summary, for a conservative estimate of the severity of the creep deformation, we may assume use of a fine-grained starting alumina ceramic and constant grain size, porosity, and diffusivity. In the case of a

13. Pruduct of Coors Porcelain Co., Golden, Colo.

14. R. L. Coble, J. Appl. Phys. 34, 1679 (1963).

15. R. L. Coblc, J. Appl. Mhys. 32, 787 (1961). 
high-purity fine-grained alumina microstructure, the Coble model is applicable. By assuming $\sigma=6.895 \mathrm{MPa}$ (1000 psi), $G=10 \mu \mathrm{m}, \Omega=1.25 \times 10^{-21} \mathrm{~cm}^{3}, P=0$, and the boundary diffusivity data in the literature, ${ }^{16}$ $W D_{B}=0.2 \exp (-125,000 / R T) \mathrm{cm}^{3} / \mathrm{sec}$, the predicted total creep strain in 40 years is as shown in Fig. 3. The relatively low magnitude of this value suggests that the results of the present calculation are conservative estimates for a safety assessment. It is also clear from this figure that very pure alumina ceramics may exhibit less than $1 \%$ creep at temperatures lower than $800^{\circ} \mathrm{C}$ and thus would be acceptable in terms of creep.

3.1.3 Fused-silica creep and devitrification. Creep of fused silica is by viscous flow and is described by

$$
\dot{\epsilon}=\sigma / \eta \text {, }
$$

where $\sigma$ is the applied stress and $\eta$ is the viscosity. If there are crystalline phases present in the fused-silica block, the creep rate should be multiplied by a factor similar to the porusity factor for dense ceramics, namely, $\left(1-\chi^{2 / 3}\right)^{-1}$, where $\chi$ is now the volume fraction of the crystalline phases.

16. A. Mocellin and W. D. Kingery, "Creep Deformation in MgO-Saturated Large-Grain-Size $\mathrm{Al}_{2} \mathrm{O}_{3}$," J. Am. Ceram. Soc. 54(7), 339-41 (1971).

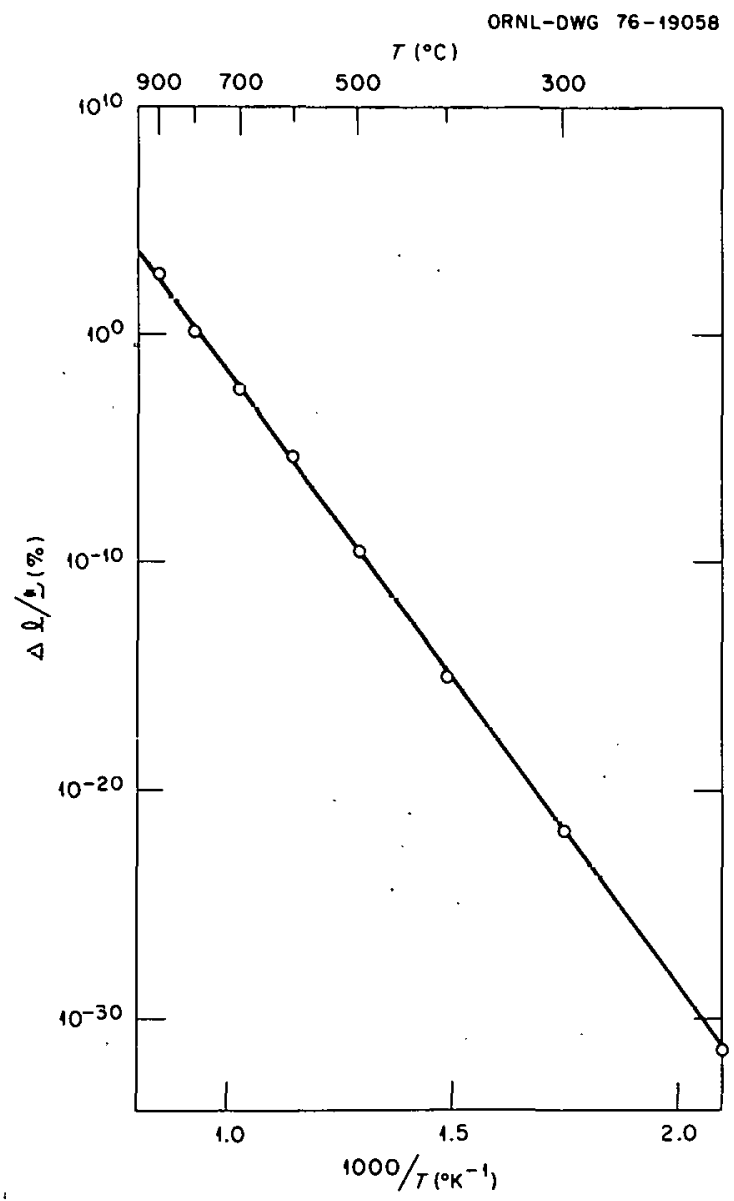

Fig. 3. Predictions of creep strain at the end of $\mathbf{4 0}$ years as a function of temperature in very pure single-phase alumina ceramics. 
Principal factors influencing the viscosity of vitreous silica are temperature, previous thermal history of the material, hydroxyl content, and metallic and other impurities. Hetherington et al. ${ }^{17}$ demonstrated that fused silicas containing higher hydroxyl concentrations have lower viscosities. Four different types of vitreous silica were investigated, namely, IR Vitreosil, ${ }^{18} \mathrm{OG}_{\text {Vitreosil }}{ }^{18}(0.027 \mathrm{wt} \% \mathrm{OH}), \mathrm{OG}_{\text {Vitreosil }}{ }^{18}$ $(0.04 \mathrm{wt} \% \mathrm{OH})$, and Spectrosil. ${ }^{18}$ The hydroxyl content in these four kinds of fused silica and their equilibrium viscosities are listed in Table 6 and shown in Fig. 4. The effect of hydroxyl is more significant at lower temperatures due to the fact that the activation energy for viscous flow is reduced as the hydroxyl concentration and the fused silica increases and the disruption of the silicon-oxygen network is increased.

There are several crystalline forms of silica, including cristobalite, tridymite, and quartz. Some of these exhibit significant disruptive phase transformations at critical temperatures. Vitreous silica will gradually

17. G. Hetherington, K. H. Jack, and J. C. Kennedy, "The Viscosity of Vitreous Silica," Phys. Chem. Glasses 5(5), 130-36 (1964).

18. Product of Thermal Syndicate Ltd., England.

Table 6. Water content and viscosity data for some commercial fused-silica products

\begin{tabular}{|c|c|c|c|c|}
\hline Type $^{a}$ & Material & $\mathrm{OH}$ or $\mathrm{Cl}(\mathrm{ppm})$ & $\begin{array}{c}\log \eta_{0} \\
{\left[\eta=\eta_{0} \exp (E / R T)\right]}\end{array}$ & $E(\mathrm{kcal} / \mathrm{mole})$ \\
\hline I & IR Vitreosil ${ }^{b}$ & $3(\mathrm{OH})$ & -12.5 & 170 \\
\hline II & OG Vitreosil (1) ${ }^{h}$ & $270(\mathrm{OH})$ & -10.6 & 154 \\
\hline II & OG Vitreosil (2) $b$ & $400(\mathrm{OH})$ & -7.7 & 131 \\
\hline III & Spectrosil ${ }^{b}$ & $1200(\mathrm{OH})$ & -6.7 & 122 \\
\hline IV & Spectrosil WF $b$ & $500(\mathrm{Cl})$ & NA & 150 \\
\hline
\end{tabular}

\footnotetext{
${ }^{a}$ Type I silica glass is produced from natural quartz by electrical fusion in a vacuum or under an inert-gas atmosphere. Type II silica glass is produced from quartz crystal powder by flame fusion. Type III silica glass is synthetic vitreous silica produced by hydrolysis of $\mathrm{SiCl}_{4}$ when spraying into an oxygen-hydrogen flame. Type IV silica glass is synthetic vitreous silica produced from $\mathrm{SiCl}_{4}$ in a water-vapor-free plasma flame.

${ }^{b}$ Product of Thermal Syndicate Ltd., England.
}

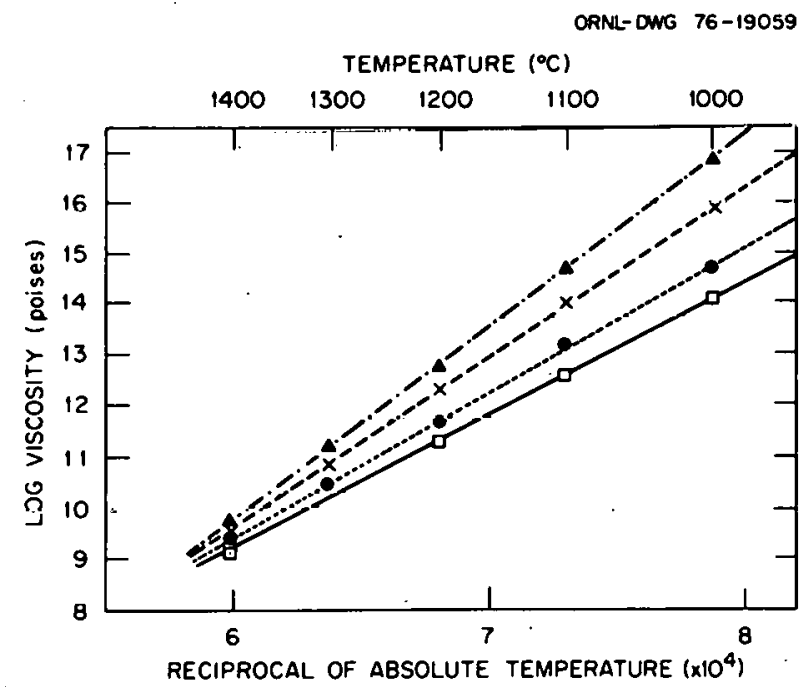

Fig. 4. Viscosity as a function of temperature for various silica glasses. (^) Type 1 (IR), (X) type II (OG with 0.027 wt $\% \mathrm{OH}$ ), (๑) type II (OG with 0.04 wt \% OH), (•) type III (Spectrosil). Data from R. Brückner, "Properties and Structure of Vitreous Silica. II,"J. Non-Cryst. Solids 5; 177-216 (1970). 
transform to cristobalite under normal atmospheric and impurity conditions. There are volume changes associated with this transformation and the $\alpha-\beta$ cristobalite transformation due to differences in molar volumes. Heterogeneities such as surface defects and impurities act as nucleation centers in vitreous silica. Water and hydroxyl ions play an important role in enhancing crystallization. An increase in the crystallization rate with increasing water vapor pressure was reported for fused silica. ${ }^{19}$ Water acts as a source of nuclei and as a means of breaking the glass structure by the incorporation of $\mathrm{H}_{2} \mathrm{O}$. Wagstaff ${ }^{19}$ determined the crystallization rate of a dehydrated silica glass at temperatures from $1300^{\circ} \mathrm{C}\left(2372^{\circ} \mathrm{F}\right)$ to $1540^{\circ} \mathrm{C}$ $\left(2804^{\circ} \mathrm{F}\right)$. The difference in growth rate can be a factor of 10 for annealing in a vacuum compared with annealing the silica in a water-rich atmosphere. A calculation was made assuming that the growth rate of cristobalite is related to the viscosity by ${ }^{20}$

$$
u=\frac{\Delta h\left(T_{m}-T\right)}{3 n u^{2} \eta T_{m}},
$$

where $u$ is the growth rate, $\Delta h$ is the heat of fusion, $T_{-m}$ is the melting point, $a$ is the molecular size, and $\eta$ is the viscosity. Using the appropriate viscosity data for silica glass containing $0.12^{1} \mathrm{wt} \%$ of hydroxyl $[\eta=4.79$ $\times 10^{22} \mathrm{~Pa} . \mathrm{s}\left(4.79 \times 10^{23}\right.$ poises $)$ at $T=500^{\circ} \mathrm{C}\left(932^{\circ} \mathrm{F}\right), \Delta h=72 \mathrm{kcal} / \mathrm{mole}, T_{m}=1700^{\circ} \mathrm{C}\left(3092^{\circ} \mathrm{F}\right), a=5$ $\AA]$, the growth rate is $10^{-7} \mu \mathrm{m} / \mathrm{min}$ at $500^{\circ} \mathrm{C}\left(932^{\circ} \mathrm{F}\right)$.

The volume fraction, $\chi$, of a sample which has transformed in a time $t$ at a given temperature may be expressed by ${ }^{2}$

$$
\chi=1-\exp \left(-\frac{\pi}{3} I_{\mathrm{v}} u^{3} t^{4}\right),
$$

where $I_{\mathrm{v}}$ is the constant nucleation rate per unit volume. The nucleation rate per unit volume can be estimated from ${ }^{22}$

$$
I_{\mathrm{v}}-N_{\mathrm{v}}^{n} \nu_{0} \exp \left(-\frac{W^{\prime *}+\Delta C_{m}}{K T}\right)
$$

where $N_{\mathrm{v}}^{0}$ is the number of molecules per unit volume, $\nu_{0}$ is a vibrational frequency $\left[N_{\mathrm{v}}^{0} \nu_{0}\right.$ is assumed as $10^{15} / \mathrm{cm}^{3}$-sec (ref. 22)], and $\Delta G_{m}$ is the activation energy for motion across the nucleus-matrix interface [assumed as $2 \mathrm{eV}$ (ref. 22)]. For heterogeneous nucleation, the work $W^{*}$ needed to form a critical nucleus is $^{22}$

$$
W^{*}=160_{\alpha \beta}^{3} f(\theta) / 3\left(\Delta G_{\mathrm{v}}\right)^{2},
$$

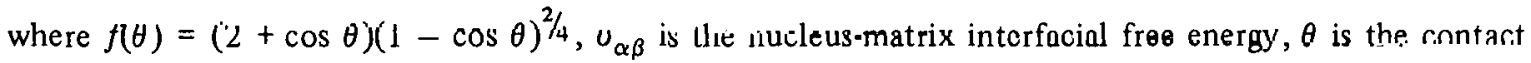
angle, and $\Delta G_{\mathrm{v}}$ is the difference in free energy per unit volume between nucleus and matrix. As $\theta$ incrcases

19. F. E. Wagstaff, S. D. Brown; and I. B. Gutler, "The Influence of $\mathrm{H}_{9} \mathrm{O}$ and $\mathrm{O}_{2}$ Atmospheres on the Crystallization of Vitreous Silica," Phys. Chem. Glasses 5(3), 76-81 (1964).

20. N. G. Ainslie, C. R. Morelock, and D. Turnbull, pp. 97-107 in Symposium on Nucleation and Crystallization in Glasses and Melts, American Ceramic Society, Columbus, Ohio, 1962.

21. D. Turnbull and M. H. Cohen, Modern Aspects of the Vitreous State, vol. 1, Butterworths, New York, 1960.

22. D. R. Uhlmann, J. F. Hays, and D. Turnbull, "The Effect of High Pressure on Crystallization Kinetics with Special Reference to Fused Silica," Phys. Chem. Glasses 7(5), 159-68 (1966). 
from $0^{\circ}$ to $90^{\circ}, f(\theta)$ changes from 0 to 0.5 . A conservative or "lower bound" estimate of $W^{*}$ is therefore 0 . Thus, at $500^{\circ} \mathrm{C}\left(932^{\circ} \mathrm{F}\right)$, the corresponding estimate of $I_{\mathrm{v}}$ is $1 \mathrm{~cm}^{-3} \mathrm{sec} .^{-1}$ Substituting 40 years as the total time in Eq. (7), the volume percent of the transformed cristobalite is, therefore, $1.3 \%$.

Uhlmann et al. ${ }^{22}$ investigated the effect of high pressure on crystallization kinetics with special reference to fused silica. It was concluded that the applied pressure had a profound effect in increasing the nucleation rate but that its effect on growth rate was rather small. The data are, however, far outside the range of interest for HTGR structural ceramics. The applied load for this investigation was $363 \mathrm{kips}$ per square inch (ksi) $(2500 \mathrm{MPa})$. At such a high pressure, crystallization in fused silica after $70 \mathrm{hr}$ at $500^{\circ} \mathrm{C}$ $\left(932^{\circ} \mathrm{F}\right)$ was significant. The kinetic formalism was not able to explain this crystallization behavior at such a low temperature and high pressure. It was attributed to the possible existence of a water-rich region at the interface at high pressure.

It is worth while to note that fission products such as $\mathrm{Cs}$ and $\mathrm{Sr}$ will tend to increase the crystallization rate of fused silica by acting as nucleation sites and promoting diffusion which enhances crystal growth rate if these fission products are deposited in significant amounts on the silica. It has been demonstrated that the addition of only $0.32 \mathrm{wt} \%$ of $\mathrm{Na}_{2} \mathrm{O}$ causes an increase in growth rate up to $670 \mu \mathrm{m} / \mathrm{min}$ at $1400^{\circ} \mathrm{C}$ $\left(2552^{\circ} \mathrm{F}\right)$, in contrast with a crystallization rate of $1.02 \mu \mathrm{m} / \mathrm{min}$ observed on similar materials in an atmosphere containing $45.2 \mathrm{~mm}$ of $\mathrm{H}_{2} \mathrm{O}^{23}$ Irradiation by fast neutrons tends to produce a volume expansion in quartz and a shrinkage in vitreous silica at cryogenic temperatures. ${ }^{24}$ Neutron fluences of $10^{20}$ neutrons $/ \mathrm{cm}^{2}$ can cause a $14 \%$ change in the molar volume of quartz and a $-3 \%$ change in fused silica at liquid nitrogen temperature. The Young's modulus of fused silica is fourd to be insensitive to irradiation; however, there can be generation of internal stress due to the absorption and scattering of the incident radiation. Irradiation can also increase the thermal conductivity of vitreous silica because the ordered or the preordered regions produced by the radiation result in a longer phonon mean free path; and at cryogenic temperatures, literature data on irradiated fused silica show a factor of 2 increase in the thermal conductivity. ${ }^{24}$ In short, irradiation by fast neutrons $\left(10^{17}\right.$ neutrons $\left./ \mathrm{cm}^{2}\right)$ will probably not have any significnt effects on the fused-silica pad under HTGR conditions $\left(>64^{\circ} \mathrm{C}\right)$.

Any crystallization or devitrification in the fused-silica pad of the ceramic support is viewed as undesirable because (1) cracks are generated as a result of crystallization, which will render the fused silica pad mechanically weak, and (2) crystallization will result in a higher effective thermal conductance in the ceramic support and thus reduce its insulation capability. The predicted amount of devitrification, $1.3 \%$, is rather significant, and this is one area of safety concern.

In the present design, Masrock ${ }^{25}$ has been selected as the fused-silica material. It contains $0.31 \mathrm{wt} \%$ water equivalent. This should yield a viscosity of $1.04 \times 10^{17} \mathrm{~Pa} \cdot \mathrm{s}\left(1.04 \times 10^{18}\right.$ poises $)$ at $600^{\circ} \mathrm{C}$ $\left(1112^{\circ} \mathrm{F}\right)$, based on extrapolation of the data in Fig. 4. If we assume normal load conditions $[\sigma=1.75 \mathrm{MPa}$ (254 psi)] and further assume that $\chi=0.01$, the creep rate $\left[\dot{\epsilon}\left(1-\chi^{2 / 3}\right)^{-1}\right.$ from Eq. (5)] is thus $1.44 X$ $10^{-11}$ in. in. ${ }^{-1} / \mathrm{sec}^{-1}$, which yields a $2 \%$ strain at the end of 40 years.

The calculated strain, $2 \%$, can only be viewed as an approximate figure because many assumptions and extrapolations were made in the calculation. However, the order of magnitude of the calculated strain does suggest that the creep in fused silica may be a problem if the criterion of $2 \%$ strain is to be met.

23. R. Brückner, "Pröerties and Structure of Vitreous Silica, I," J. Non-Cryst. Solids 5, 123-75 (1970).

24. R. Brückner, "Properties and Structure of Vitreous Silica. II," J. Non-Cryst. Solids 5, 177-216 (1970).

25. Product of Glasrock Co., Atlanta, Ga. 


\subsection{Reaction between Ceramics}

From the safety point of view, reactions between ceramic members should be carefully assessed. Some reactions will produce new phases, and the volume changes associated with the generation of these phases can cause cracks. The constraint of the core weight would further aggravate the situation.

The case of $\mathrm{Si}_{3} \mathrm{~N}_{4}$ reactions with graphite and $\mathrm{Si}_{3} \mathrm{~N}_{4}$ decomposition has been analyzed by Hankart and others. ${ }^{26}$ The following discussion on $\mathrm{Si}_{3} \mathrm{~N}_{4}$ is taken from their work. Silicon nitride can react with the graphite seat according to

$$
\mathrm{Si}_{3} \mathrm{~N}_{4}+3 \mathrm{C} \rightarrow 3 \mathrm{SiC}+2 \mathrm{~N}_{2}
$$

The standard free energy change for this reaction is

$$
\Delta \hat{G}_{(1)}^{n}--R T \ln \Gamma_{\mathrm{N}_{2}}
$$

where $P_{\mathrm{N}_{2}}$ is the partial pressure of nitrogen. The dissociation of silicon nitride occurs by

$$
\mathrm{Si}_{3} \mathrm{~N}_{4} \rightarrow 3 \mathrm{Si}+2 \mathrm{~N}_{2}
$$

and

$$
\Delta G_{(2)}^{\circ}=-R T \ln P_{\mathrm{N}_{2}}
$$

The published data for the standard free energies of reactions (10) and (11) showed ${ }^{2}$

$$
\begin{aligned}
& \Delta G_{(1)}^{\circ}=67.50+0.93 T \log T-39.63 T, \\
& \Delta G^{\circ}{ }_{(2)}=88.50+2.88 T \log T-48.15 T .
\end{aligned}
$$

These data suggest the equilibrium partial pressures of nitrogen uver $\mathrm{Si}_{3} \mathrm{~N}_{4}$ given in Table 7 .

2.6. I. .I. Hankart, L. Mayr, and G. Worrall, Preliminary Investigations into the Compatibllty of Ceramics with HTR Helium in the Dragon Reactor, D.P. Rep. 965 (November 1975).

27. V. Kubaschewski, E. L. P. Evans, and C. B. Alcock, Metallurgical Thermochemistry, 4th ed., Pergamon Press, New York, 1967.

Table 7. Equilibrium partial pressures of nitrogen over $\mathrm{Si}_{3} \mathrm{~N}_{4}$

\begin{tabular}{cccc}
\hline \multicolumn{2}{c}{ Temperature } & $\mathrm{N}_{2}$ dissociation pressure, reaction (11) \\
(atm) & $\begin{array}{c}\mathrm{N}_{2} \text { pressure when } \mathrm{Si}_{3} \mathrm{~N}_{4} \\
\text { reacts with carbon, reaction (10) } \\
\text { (atm) }\end{array}$ \\
\hline 700 & 12.92 & $5.0 \times 10^{-12}$ & $8.0 \times 10^{-8}$ \\
800 & 1472 & $4.0 \times 10^{-10}$ & $2.0 \times 10^{\circ}$ \\
900 & 1652 & $1.3 \times 10^{-8}$ & $3.0 \times 10^{-5}$ \\
1000 & 1832 & $2.5 \times 10^{-7}$ & $2.1 \times 10^{-4}$ \\
1100 & 2012 & $3.0 \times 10^{-6}$ & $2.0 \times 10^{-2}$ \\
1200 & 2192 & $2.0 \times 10^{-5}$ & $1.0 \times 10^{-2}$ \\
\hline
\end{tabular}


Since the HTGR coolant has a partial pressure of nitrogen in the range of microatmospheres, silicon nitride should react with carbon at temperatures above $900^{\circ} \mathrm{C}\left(1652^{\circ} \mathrm{F}\right)$.

Alumina is a very stable oxide, but there is a possibility of reaction between alumina and silicon nitride or silica in the worst case in which the Grafoil between pads would not act as a reaction barrier and ceramic pads would be in direct contact with each other:

$$
\begin{aligned}
& \mathrm{Al}_{2} \mathrm{O}_{3}+\mathrm{Si}_{3} \mathrm{~N}_{4} \rightarrow \text { (Sialon) material } \\
& 3 \mathrm{Al}_{2} \mathrm{O}_{3}+2 \mathrm{SiO}_{2} \rightarrow 3 \mathrm{Al}_{2} \mathrm{O}_{3} \cdot 2 \mathrm{SiO}_{2}
\end{aligned}
$$

The production of mullite will bring about a volume expansion in alumina and shrinkage in fused silica. Sialon (a silicon aluminum oxynitride) has a higher density than silicon nitride but a lower density than alumina. Hence, there will be a volume expansion on the silicon nitride side and a shrinkage on the alumina side of the interface between silicon nitride and alumina.

Another important consideration is the effect that the generation of these new phases has on the stress distribution in the pad material. This can be analyzed from the thickness of the solid-state reaction layer that forms. Aluminum ions diffuse more rapidly than the other elements in this system, and the $\mathrm{Al}_{2} \mathrm{O}_{3}$ $\mathrm{Si}_{3} \mathrm{~N}_{4}$ interface is at a higher temperature than the bulk of the alumina pad. The diffusivity $\left(D^{*}\right.$ of $\left.\mathrm{Al}\right)$ at the temperature corresponding to the $\mathrm{Al}_{2} \mathrm{O}_{3}-\mathrm{Si}_{3} \mathrm{~N}_{4}$ interface is $10^{-13} \mathrm{~cm}^{2} / \mathrm{sec} .^{16}$ This yields a reaction layer thickness of about $100 \mu \mathrm{m}$ in 40 years. The internal stress buildup due to this new phase can be estimated from

$$
\sigma=\frac{2 E \Delta V / V}{3(1-\nu)},
$$

where $E$ is the Young's modulus, $\nu$ is Poisson's ratio, and $\Delta V / V$ is the volume change. In all cases, the stress will be less than about $3 \mathrm{MPa}(500 \mathrm{psi})$. The thermal insulation character of the column will probably not be influenced by such small thicknesses $(100 \mu \mathrm{m})$ of new phases. Therefore, it is felt that the reaction between adjacent pads, if it occurs, will not create a serious safety hazard.

Observations on the failure modes of fused silica under compressive load show that cracks normally start from the specimen-compression-anvil interfaces and propagate longitudinally through the specimen. Tlus type of cracking is due to tension from frictional forces which are developed by the different lateral strains on the two sides of the interfaces. These strains are generated due to the abrupt changes in elastic properties at the interfaces. It is common practice to insert a fibrous material that will distribute and transmit compressive forces without developing high frictional forces. For this reason, Grafoil, which is a graphite flake felt material, is to be used between adjacent ceramic members. Due to this feature of the column design, the compatibility of carbon with alumina and silica is important. Although, as was stated previously, $\mathrm{Si}_{3} \mathrm{~N}_{4}$ will react with carbon above $900^{\circ} \mathrm{C}\left(1652^{\circ} \mathrm{F}\right)$, alumina will not be reduced by carbon under these conditions. There is no evidence of other reaction products between alumina and carbon in the temperature ranges anticipated for the HTGR. Carbon does reduce silica at temperatures above $1400^{\circ} \mathrm{C}$ $\left(2552^{\circ} \mathrm{F}\right)$. The reaction is

$$
\mathrm{SiO}_{2}+\mathrm{C} \rightarrow \mathrm{Si}+\mathrm{CO}_{2} \text {. }
$$

The standard free energy fur this reaction is ${ }^{27}$ 


$$
\Delta G^{\circ}=121,400-41.7 T
$$

and in terms of equilibrium $\mathrm{CO}_{2}$ partial pressure it is

$$
\Delta G^{\circ}=-R T \ln P_{\mathrm{CO}_{2}}
$$

Equating these two expressions yields an equilibrium partial pressure of $\mathrm{CO}_{2}$ of $10^{-13}$ atm at a temperature of $900^{\circ} \mathrm{C}\left(1652^{\circ} \mathrm{F}\right)$. This is much less than the partial pressure of $\mathrm{CO}_{2}\left(10^{-6} \mathrm{~atm}\right)$ in the helium coolant under normal conditions. Thus, reaction of silica with carbon under HTGR coolant conditions should not occur. Other candidate materials for the application of better load distribution in place of Grafoil arc Saffil alumina fiher ${ }^{28}$ and Fiberfrax paper. ${ }^{29}$

\subsection{Cuülant Corrooion}

The oxidation behavior of the ceramic materials should also be considered in a safety analysis. The high-temperature stability of $\mathrm{Si}_{3} \mathrm{~N}_{4}$ in an oxidizing atmosphere is related to the formation of an amorphous $\mathrm{SiO}_{2}$ layer on its surface. The reaction is

$$
\mathrm{Si}_{3} \mathrm{~N}_{4}+3 \mathrm{O}_{2} \rightarrow 3 \mathrm{SiO}_{2}+2 \mathrm{~N}_{2}
$$

In air; oxidation of silicon nitride is detectable at $700^{\circ} \mathrm{C}\left(1292^{\circ} \mathrm{F}\right)$ after only $24 \mathrm{hr}^{30}$ Vitreous silica formed on the surface of silicon nitride was also found to transform into cristobalite, which generated cracks in the $\mathrm{SiO}_{2}$ layer. In low-oxygen-potential atmospheres the formation of an $\mathrm{SiO}_{2}$ film will limit further oxidation. In a highly oxidizing atmosphere, reactions such as the following can occur:

$$
\begin{aligned}
& \mathrm{Si}_{3} \mathrm{~N}_{4}+3 \mathrm{SiO}_{2} \rightarrow 6 \mathrm{SiO}(\mathrm{g})+2 \mathrm{~N}_{2} \\
& 2 \mathrm{Si}_{3} \mathrm{~N}_{4}+3 \mathrm{O}_{2} \rightarrow 6 \mathrm{SiO}(\mathrm{g})+4 \mathrm{~N}_{2}
\end{aligned}
$$

Calculations also show that oxidation due to formation of gaseous $\mathrm{SiO}$ will only occur at an oxygen pressure of $8 \times 10^{-4} \mathrm{~atm}$ or more at $1600^{\circ} \mathrm{C}\left(2912^{\circ} \mathrm{F}\right) .^{31}$

Singhal's data ${ }^{32}$ on the oxidation rate of $\mathrm{Si}_{3} \mathrm{~N}_{4}$ can be expressed by

$$
W^{2}=K_{p} t
$$

where $W$ is the weight gain at time $t$ and $K_{p}$ is a rate constant that can be expressed as

$$
K_{p}=4.03 \times 10^{3} \exp \left(-\frac{89.6}{R T}\right) \frac{\mathrm{kg}^{2}}{\mathrm{~m}^{4} \mathrm{sec}}
$$

28. Product of ICI United States, Wilmington, Del.

29. Product of Carborundum Co., Niagara Falls, N.Y.

30. A. J. Kiehle, L. K. Heung, D. J. Gielisse, and T. J. Rockett, "Oxidation Behavior of Hot-Pressed $\mathrm{Si}_{3} \mathrm{~N}_{4}$,"J. $A m$ Ceram. Soc. 58(1-2), 17-20 (1975).

31. S. C. Singhal, in Proceedings of the 1974 Gas Turbine Materials in the Marine Environment Conference, ed. J. W. Fairbanks and I. Machliw, Battelle's Metals and Ceramics Information Center, Rep. 75-27, p. 311 (1975).

32. S. C. Singhal, "Thermodynamics and Kinetics of Oxidation of Hot-Pressed Silicon Nitride," J. Mater. Sci 11, 500-509 (1976). 
and is independent of ambient oxygen and nitrogen partial pressures. If $T=1000^{\circ} \mathrm{C}\left(1832^{\circ} \mathrm{F}\right)$ and $t=40$ years, these expressions yield $W=5.15 \times 10^{-3} \mathrm{~g} / \mathrm{cm}^{2}$, or, equivalently, a thickness of $15 \mu \mathrm{m}$.

Magnesium and calcium impurities also influence the oxidation behavior of $\mathrm{Si}_{3} \mathrm{~N}_{4}$. At high temperatures they tend to diffuse out of the grain-boundary regions, forming silicates on surfaces and thus lowering the oxidation resistance. In low-oxygen-potential atmospheres the formation of an $\mathrm{SiO}_{2}$ film will limit further oxidation.

It has been proposed that diffusion of $\mathrm{Mg}^{2+}$ and $\mathrm{Ca}^{2+}$ cations from the grain-boundary glassy phase through the oxide film is the rate-controlling process for oxidation. ${ }^{32}$ However, in commercial $\mathrm{Si}_{3} \mathrm{~N}_{4}$, which contains more $\mathrm{Mg}$ or $\mathrm{Ca}$, the oxidation rates may be much higher than those reported by Singhal.

The above calculations did not include the consideration that $\mathrm{CO}, \mathrm{CO}_{2}$, and $\mathrm{H}_{2}$ in the HTGR coolant will attack the amorphous $\mathrm{SiO}_{2}$ film on $\mathrm{Si}_{3} \mathrm{~N}_{4}$. Reaction of hydrogen with silica has been reported at $927^{\circ} \mathrm{C}\left(1700^{\circ} \mathrm{F}\right)$ as

$$
\mathrm{H}_{2}+\mathrm{SiO}_{2} \rightarrow \mathrm{SiO}+\mathrm{H}_{2} \mathrm{O}
$$

The data of Crowley show that for an exposed surface at $1000^{\circ} \mathrm{C}\left(1832^{\circ} \mathrm{F}\right)$, a flow rate of 35 liters $/ \mathrm{min}$ and $1 \mathrm{~atm}$ of $\mathrm{H}_{2}$ can cause a $1 \%$ weight loss in $6 \mathrm{hr}^{3{ }^{3}}$ If the weight loss varies linearly with pressure and flow rate, then the rate of weight loss of $\mathrm{SiO}_{2}$ in an $\mathrm{HTGR}$ can be estimated at $1.07 \times 10^{-11} \mathrm{~g} \mathrm{~cm}^{-3} \mathrm{sec}^{-1} \mathrm{On}$ the other hand, the oxidation rate was calculated to be $15 \mu \mathrm{m}$ in 40 years, or $6.2 \times 10^{-18} \mathrm{~g} \mathrm{~cm}^{-3} \mathrm{sec}^{-1}$ Therefore, it appears that all the protective silica film on $\mathrm{Si}_{3} \mathrm{~N}_{4}$ can be effectively etched away by hydrogen. The total amount of loss would be limited by the amount of silica generated, a layer $15 \mu \mathrm{m}$ thick.

The lower fused-silica support pad will also be subjected to reaction with $\mathrm{H}_{2}$. Using a weight loss rate of $1.07 \times 10^{-11} \mathrm{~g} \mathrm{~cm}^{-3} \mathrm{sec},-1$ a loss of less than $0.1 \%$ is predicted. The weight loss will occur primarily at exposed surfaces. Such a small weight loss might be of no consequence to the design, but the pits generated on the surface could act as surface flaws and might be a safety concern.

\subsection{Fatigue}

Structural ceramics and glasses generally exhibit a decrease in load-bearing ability under conditions of constant or cyclic load and thermal cycling. These phenomena are commonly referred to as static, cyclic, and thermal fatigue. Such behavior is the result of slow crack growth at stress levels below those required for rapid or catastrophic fracture. For reliable engineering design with structural ceramics, a detailed understanding of these fatigue phenomena in terms of strength degradation is imperative.

Lange ${ }^{34}$ has obtained some evidence of subcritical crack growth in commercial hot-pressed $\mathrm{Si}_{3} \mathrm{~N}_{4}$. Fracture surfaces showed rough, crack-shaped topographic features, and large cracks formed during stressing. Evans and Wiederhorn ${ }^{35}$ formulated the problem of fatigue in $\mathrm{Si}_{3} \mathrm{~N}_{4}$ on the basis of fracture mechanics. The time to failure due to slow crack propagation is

$$
t=\cdots \frac{2}{\alpha(n-2) \sigma_{a}^{2} Y^{2} K_{Y \bar{C}}^{2}}\left[\left(\frac{\sigma_{p}}{\sigma_{a}}\right)^{n-2}-1\right],
$$

33. M. S. Crowley, "Hydrogen Silica Reactions in Refractories - II," Bull. Am. Ceram. Soc. 49(5), 527-30 (1970).

34. F. F. Lange, "High-Temperature Strength Behavior of Hot-Pressed $\mathrm{Si}_{3} \mathrm{~N}_{4}$ : Evidence for Subcritical Crack Growth," J. Am. Ceram. Soc. 57(2), 84-87 (1974).

35. A. G. Evans and S. M. Wiederhorn, "Crack Propagation and Failure Prediction in Silicon Nitride at Elevated Temperatures," J. Mater. Sci. 9, 270-78 (1974). 
where $\alpha$ and $n$ are defined by $d a / d t=\alpha K_{I}^{n}, a$ is the crack length, $K_{I}=\alpha Y a^{1 / 2}, Y$ is a geometric factor, $K_{I}$ is a stress intensity factor, $\sigma_{a}$ is the applied stress, $\sigma_{p}$ is the proof stress (stress required to extend the largest flaw that can exist at the limit of nondestructive examination), and $K_{I C}$ is the critical stress intensity factor. According to their calculations and experimental data, a static load of $1034 \mathrm{MPa}(150 \mathrm{ksi})$ can cause failure within 40 years, at $1000^{\circ} \mathrm{C}\left(1832^{\circ} \mathrm{F}\right)$ at a ratio of proof stress to applied stress of $2: 1$. A proof test diagram is reproduced in Fig. 5. A stress of about $6.895 \mathrm{MPa}(1000 \mathrm{psi})$, or, equivantly, $6.895 \mathrm{MN} / \mathrm{m}^{2}$, probably will not cause failure within 40 years according to a relation established for hot-pressed $\mathrm{Si}_{3} \mathrm{~N}_{4}$ that was tested at $300^{\circ} \mathrm{C}\left(572^{\circ} \mathrm{F}\right)$ by bend tests in a water-saturated almosphere. ${ }^{35}$ This relation is

$$
S_{t}=111,300(1-0.010 \log t)
$$

where $t$ is the time (min) to fail under strcss $S_{t}$ (psi). Although the time to failure is very long, a reduction in compressive strength during the 40-year life could be signiticant. There are cuncully niv data in thio lond range. A reduction in compressive strength could reduce the stress safety factor to an unacceptable value.

It is well known that alumina ceramics exhibit dclayed failute, or static fatigue. Early experiments were conducted on low-density sintered alumina at room temperature. At high temperatures, both hydrogen and oxygen atmospheres were shown to affect the compressive strength as a result of the static fatigue phenomenon. Compression tests on alumina ceramics in nitrogen-watcr atmospheres clearly demonstrated that

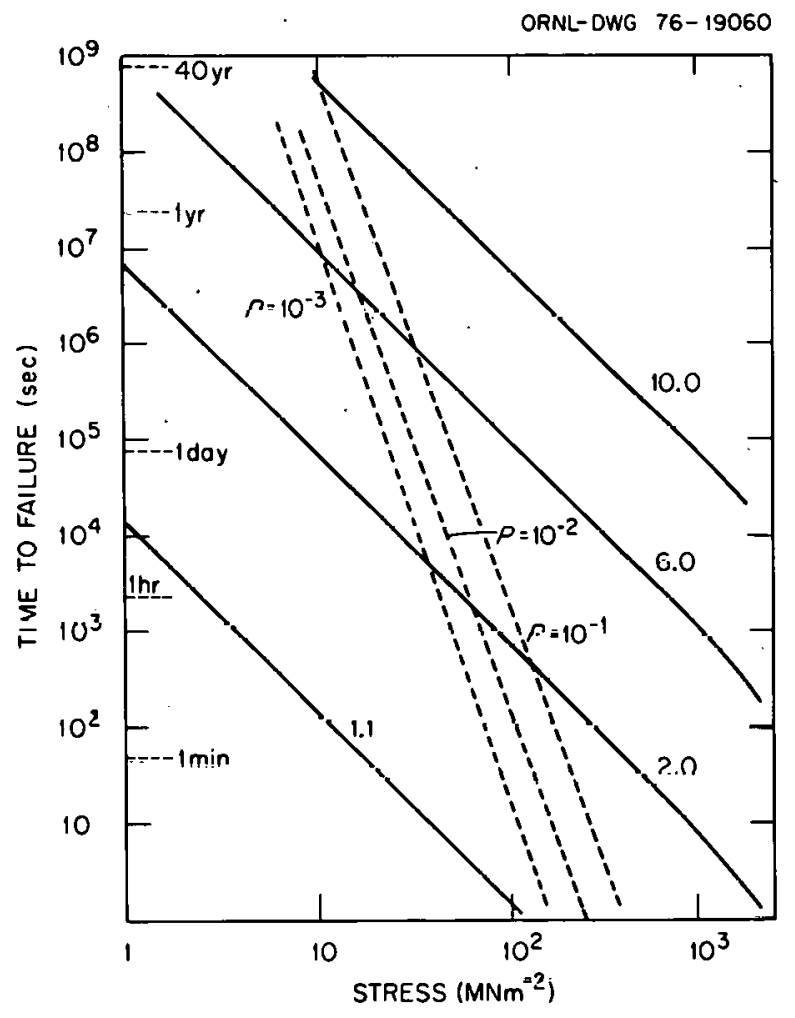

Fig. 5. Time to failure as a function of stress for silicon nitride ceramics at $1400^{\circ} \mathrm{C}$. The parameter associated with each solid line is the ratio of the proof stress to the applied stress. The dotted lines are approximate values for the time to failure without proof testing for various failure probabilities (P). From. A. G. Evans and S. M. Wiederhorn, J. Mater. Sci. 9, 270-78 (1974). 
static fatigue or stress corrosion would occur. It was shown that the worst case of strength loss occurred when stress and the corrosive atmosphere were applied simultaneously. In the case of alumina, water vapor is the most deleterious atmosphere for causing fatigue. The reaction products at crack tips are hydrates. Figure 6 illustrates the effect of water vapor on the bend strength of standard Lucalox alumina ${ }^{36}$ ceramics. At about $850^{\circ} \mathrm{C}\left(1562^{\circ} \mathrm{F}\right)$, it appears that the corrosion and fatigue effects have largely disappeared. Charles $^{37}$ formulated the problem from the change of the flaw contour, the change in stress distribution, and the relationship between these two. The basic equation he derived is

$$
S_{L}=\left(3 \sigma_{\mathrm{th}} \Gamma V_{M} / 8 V^{*} L\right)^{1 / 2}
$$

where $S_{L}\left(\mathrm{~kg} / \mathrm{cm}^{2}\right)$ is the fatigue limit stress below which no failure of the specimen can occur, $\sigma_{\mathrm{th}}$ $\left(\mathrm{kg} / \mathrm{cm}^{2}\right)$ is the theoretical strength of the material, $L$ is the initial depth of the flaw, $V^{*}$ is the activation volume $\left(\mathrm{cm}^{3} / \mathrm{mole}\right), V_{M}$ is the molecular volume $\left(\mathrm{cm}^{3} / \mathrm{mole}\right)$, and $\Gamma\left(\mathrm{ergs} / \mathrm{cm}^{2}\right)$ is the surface energy between the solid and the corrosion product. Furthermore,

$$
\ln \frac{t}{t_{0.5}} \simeq-\frac{V^{*}}{R T} \sigma_{\mathrm{th}}\left(\frac{S}{S_{N}}-\frac{1}{2}\right)-f\left(\frac{S}{S_{N}}\right)
$$

where $t$ is the time to failure, $t_{0.5}$ is the time to failure at one-half the liquid-nitrogen applied stress $\left(S_{N}\right)$, and $f\left(S / S_{N}\right)$ is a slowly varying function. A schematic fatigue curve is presented in Fig. 7 . The data indicate that the maximum reduction of the intrinsic strength of alumina by corrosion fatigue is approximately $80 \%$. A stress of $142 \mathrm{MPa}(20,600 \mathrm{psi})$ was considered the fatigue limit stress for Lucalox alumina. Stresses below this value probably will not cause fracture for times not exceeding $10^{4} \min (\approx 7$ days $)$.

36. Product of General Electric Co., Schenectady, N.Y.

37. R. J. Charles and R. R. Shaw, Delayed Failure of Polycrystalline and Single-Crystal Alumina, GE Rep. 62-RL-3081M (1962).

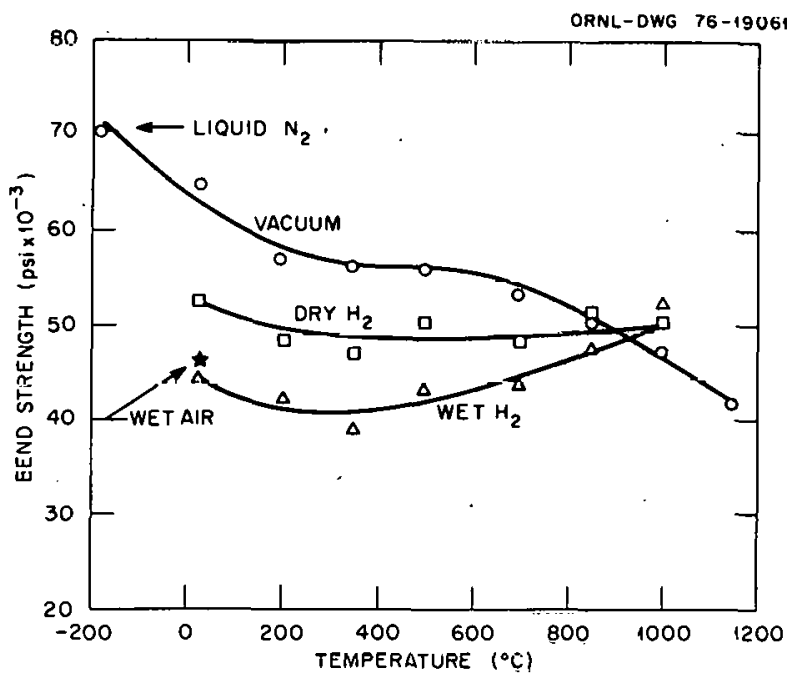

Fig. 6. Temperature-atmosphere effects on the bend strength of standard Lucalox alumina specimens. From R. I. Charles and R. R. Shaw, Delayed Failure of Polycrystalline and Single-Crystal Alumina, GE Rep. 62-RL-3081 M (1962). 


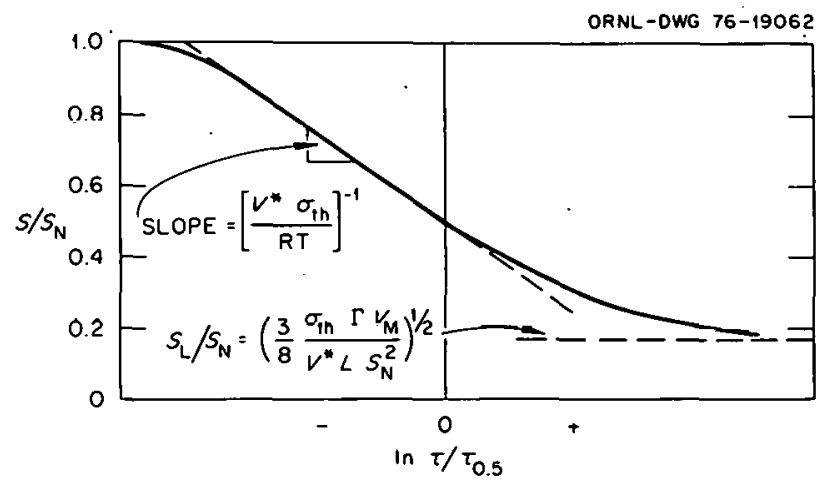

Fig. 7. Schematic fatigue curve for alumina. $\tau$ is the time to failure, and $\tau_{0.5}$ is the time to failure for a stress of $S_{N} / 2$. From R. J. Charles and R. R. Shaw, Delayed Failure of Polycrystalline unid Single-Crystal Aluminu, GE Rep. 62-RL-3081M (1467).

The theoretical strength, $\sigma_{\mathrm{th}}$, can be estimated as $E / 5$, or approximately $7 \times 10^{5} \mathrm{~kg} / \mathrm{cm}^{2}$. The activation volume, $V^{*}$, is about $0.5 \mathrm{~cm}^{3} /$ mole. At $800^{\circ} \mathrm{C}\left(1472^{\circ} \mathrm{F}\right), V^{*} \sigma_{\text {th }} / R T$ is 5.10 . The function $f\left(S / S_{N}\right)$ was estimated as $-1.3 .^{23}$ Now, consider $S=6.895 \mathrm{MPa}(1000 \mathrm{psi}), S / S_{N}=1 / 90, t_{0.5}=7 \mathrm{~min}$; then Eq. (27) predicts that $t$ is only $5 \mathrm{hr}$. This implies that alumina in a water-saturated atmosphere at $800^{\circ} \mathrm{C}\left(1472^{\circ} \mathrm{F}\right)$ can fail under a load of $6.895 \mathrm{MPa}(1000 \mathrm{psi})$ within $5 \mathrm{hr}$. However, it is difficult to assess the reliability of predictions of this type, because of the many approximations and assumptions that have been used in the calculation, plus the lack of experimental dala.

There are numerous studies in the open literature on stress-corrosion effects in silicate systems. Delayed failure in fused quartz in an atmosphere containing $\mathrm{H}_{2} \mathrm{O}$ is a well-established fact. Compressive tests indicated that a typical value for $S_{L} / S_{N}$ is $0.155^{38}$ Compared with $\mathrm{Al}_{2} \mathrm{O}_{3}$, the safety margin for fatigue failure is less in the case of fused silica $\left(S_{L} / S_{N}\right.$ for $\mathrm{Al}_{2} \mathrm{O}_{3}$ is about 0.2). Orie set of test data shows that at $240^{\circ} \mathrm{C}\left(464^{\circ} \mathrm{F}\right)$, fused quartz has different compressive strengths under dynamic loading in dry nitrogen and saturated water vapor atmospheres. ${ }^{j \dot{y}}$ The difference is as much as a factor of 2 . The universal fatigue equation derived by Wiederhorn et al. ${ }^{38}$ is

$$
\frac{S}{S_{N}}=0.5-\frac{2.3 R T}{6 K_{I C}} \log \frac{t}{t_{0.5}},
$$

where $\bar{K}_{I C}$ is the critical stress intensity factor at llquid-niliugen temperaturc, $K_{I C}-5 \times 10^{5} \mathrm{NM}^{-3} / 2$ at $200^{\circ} \mathrm{C}\left(392^{\circ} \mathrm{F}\right), b$ is a parameter characterizing the crack growth rate, $b=0.216$ (in the mks systcm), and $t_{0.5}=\left(\pi R T K_{I C} / b \nu_{0.5}\right) \sigma_{N}^{-2}$. Data on fatigue in silicate glass obtained by Mould and Suullıwick, ${ }^{40}$ Proctor et al., ${ }^{41}$ and Wiederhorn and Boltz ${ }^{38}$ are shown in Fig. 8. Eyuation (28) prcdicts [using Mould's datia. $\iota_{0.3}$ $\cong 10 \mathrm{sec}$ and $\left.\sigma_{N}=453 \mathrm{MPa}(65,700 \mathrm{psi})\right]$ a failure time of only three months for a stress of $6.895 \mathrm{MPa}$ $(1000 \mathrm{psi})$ and a temperature of $400^{\circ} \mathrm{C}\left(752^{\circ} \mathrm{F}\right)$. Here again, because of the limitation of applicability of Eq. (28), which has only been demonstrated to be valid up to $10^{4} \mathrm{sec}$, the three-month failure time only indicates that fatigue in fused slica may be of safety concent.

38. S. M. Wiederhorn and L. H. Bolz, "Stress Corrosion and Static Fatigue of Glass," J. Am. Ceram. Soc. 53(10), $543-48(1970)$.

39. R. J. Charles, The Strength of Silicate Glasses and Some Crystalline Oxides, GE Rep. 59-RL-2203 (1959).

40. R. E. Mould and R. D. Southwick, J. Am. Ceram. Soc. 42, 489 (1959).

41. B. A. Proctor, J. Whitney, and J. W. Johnson, Proc. R. Soc. London A297, 534 (1967). 


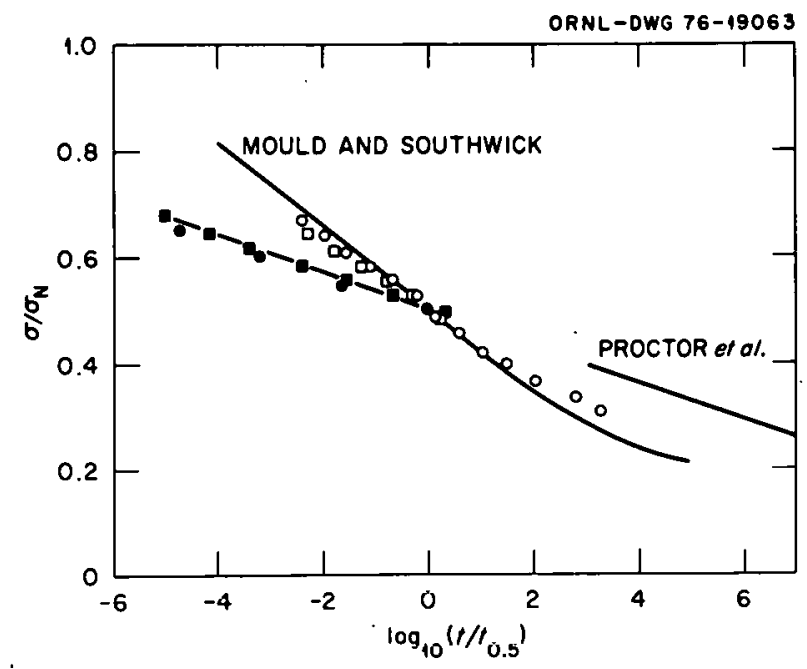

Fig. 8. Crack propagation data for silicate glass. Closed circles and squares were obtained from fused-silica crack velocity data [S. M. Wiederhorn and L. H. Bolz, J. Am. Ceram. Soc. 53, 543-48 (1970)]. Open circles and squares were obtained from soda-lime-silica glass crack velocity data. Curves were taken from R. E. Mould and R. D. Southwick, J. Am. Ceram. Soc. 42, 489 (1959) and B. A. Proctor, J. Whitney, and J. W. Johnson, Proc. R. Soc. London A297, 534 (1967).

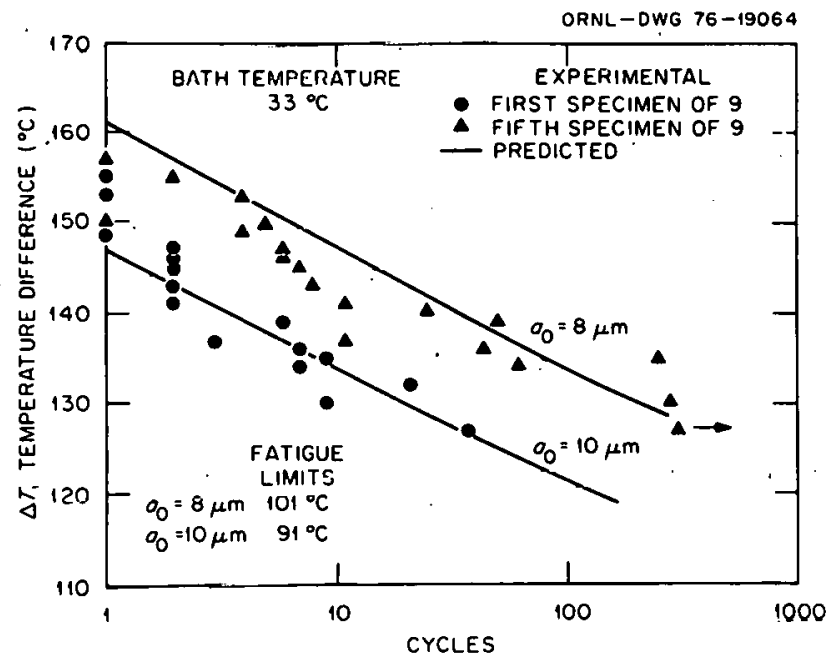

Fig. 9. Predicted and experimental cycles to failure for soda-lime-silica glass ruds. From D. P. H. Hasselman et al., J. Mater. Sci. 11, 458-64 (1976).

Other fatiguc modes, such as cyclic fatigue and thermal fatigue, probably are less important than static fatigue. Temperature cycling $\left[\Delta T=111^{\circ} \mathrm{C}\left(200^{\circ} \mathrm{F}\right)\right]$ has a frequency of 1 per day, and over a 40 -year life the total number of cycles will be about $10^{4}$. Hasselman's thermal fatigue data ${ }^{42}$ on soda-lime-silicate glass are shown in Fig. 9. A total number of 100 cycles and a quench temperature differential of $102^{\circ} \mathrm{C}\left(216^{\circ} \mathrm{F}\right)$ to a bath of water at $33^{\circ} \mathrm{C}\left(y 1^{\circ} \mathrm{F}\right)$ can cause failure. No analytical relationship for these variables is available. At temperatures above $216^{\circ} \mathrm{C}\left(421^{\circ} \mathrm{F}\right)$, no cyclic fatigue was observed in alumina. ${ }^{43}$ The role of cyclic stress on the fatigue behavior of glass was found to be negligible. ${ }^{42}$

42. D. P. H. Hasselman, R. Badaliance, K. R. McKinney, and C. H. Kim, "Failure Prediction of the Thermal Fatigue Resistance of a Glass," J. Matcr. Sci. 11, 458-64 (1976).

43. C. P. Chen and W. J. Knapp, "Fatigue Fracture of Alumina Ceramics at Several Temperatures," in Symposium on the Fracture Mechanics of Ceramics, vol. 2, ed. R. C. Bradt, D. P. H. Hasselman, and F. F. Lange, Plenum Press, New York, 1973. 
In summary, static fatigue in the HTGR structural ceramics may reduce the compressive strength significantly, while thermal fatigue or cyclic fatigue probably has little influence on the load-bearing capability of these materials.

As was mentioned above, there are many difficulties in trying to extrapolate literature data to HTGR conditions. For example, (1) the stress in the HTGR structural ceramics application is generally much smaller than the stress range of all the studies in the literature, (2) the temperature range is not within most of the investigated cases, and (3) the HTGR coolant condition has a water vapor partial pressure on the order of a few microatmospheres, which is much smaller than in the water-saturated atmospheres used in most of the past studies. In any event, further experimental data on static fatigue should be obtained to justify and support the present design.

\subsection{Thermal Stresses}

In addition to strinstural loading, the ceramic support system in ain HTGR lias lio function of thermal insulation. The stability of the thermal insulation properties is essential to the reactor core and the suppuit floor. Thermal conduction can be assessed from the physical propertics auch as $K$ (thermal rnnductivity), $C_{p}$ (heat capacity), and $\rho$ (density) of the materials. The heat transfer equation is

$$
\rho C_{P} \frac{\partial T}{\partial t}=\nabla \cdot K \nabla T
$$

where $T$ is the temperature.

Computer subroutine HEATING 3 (ref. 44) was used to calculate the temperature distribution in the structural ceramic members. Steady-state conditions were assumed, and a cylindrical coordinate system was used with the origin placed at the center of the fused-silica pad, as shown in Fig. 10. The calculation is of a

44. W. D. Turner and M. Siman-Tov, HEATING 3 - an IBM 360 Heat Conduction Program, ORNL/TM-3208 (February 1971).

ORNL-DWG $76-19065$

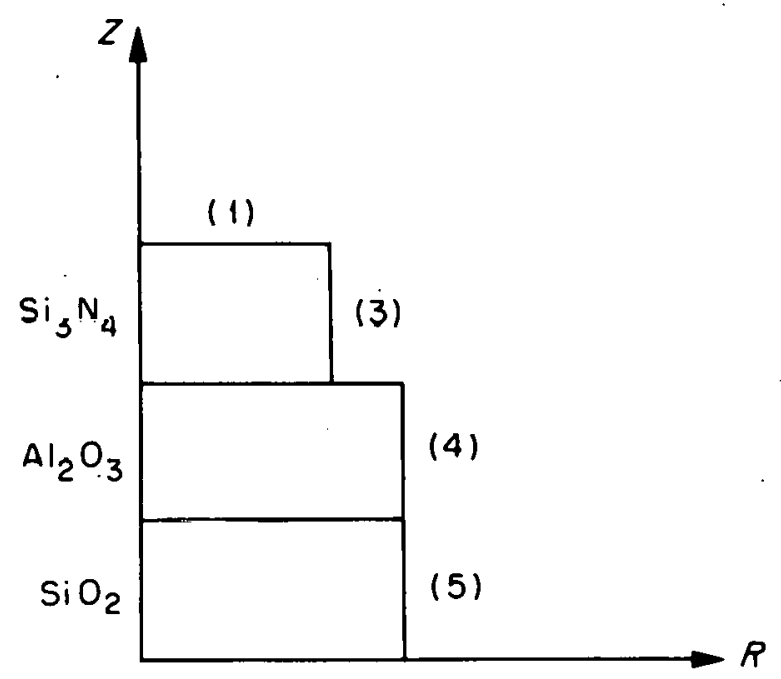

(2)

Fig. 10. Coordinate system and boundaries for calculating temperature distribution in structural ceramics. Boundaries 1 and 2 are surface-to-boundary type, with the boundary being isothermal. Boundaries 3,4 , and 5 are insulated. 
preliminary nature in that assumptions on boundary conditions were made. The top surface of the silicon nitride and the bottom surface of the fused silica were assumed to be surface-to-boundary types with the isothermal boundaries being at $899^{\circ} \mathrm{C}\left(1650^{\circ} \mathrm{F}\right)$ and $58^{\circ} \mathrm{C}\left(136^{\circ} \mathrm{F}\right)$, respectively, since they are in contact with the graphite seat and metal liners, which are relatively good thermal conductors. The heat transfer coefficients are: $198 \mathrm{~W} \mathrm{~m}^{-2} K^{-1}\left(34.9 \mathrm{Btu} \mathrm{hr}^{-1} \mathrm{ft}^{-2}{ }^{\circ} \mathrm{F}^{-1}\right.$ ) (forced convection, $h_{c}$ ), $3.69 \mathrm{~W} \mathrm{~m}^{-2} K^{-1}$ $\left(0.65 \mathrm{Btu} \mathrm{hr}^{-1} \mathrm{ft}^{-2}{ }^{\circ} \mathrm{F}^{-1}\right.$ ) (natural convection exponent, $h_{e}$ ), $1.38 \times 10^{-9} \mathrm{Btu} \mathrm{hr}^{-1} \mathrm{ft}^{-2}{ }^{\circ} \mathrm{F}^{-4}$ (radiation, $h_{r}$ ). The flux is given by

$$
|J|=h_{c} \Delta T+h_{r}\left(T_{1}^{4}-T_{2}^{4}\right)+H_{n} \Delta T^{h_{e}} \Delta T,
$$

where $\Delta T$ is the temperature difference between points 1 and 2 , namely, $T_{1}-T_{2}$. The cylindrical surfaces of the three pads were assumed insulated with no heat flux. In steady state, Eq. (29) reduces to

$$
\nabla \cdot K \nabla T=0 .
$$

The thermal conductivity data used in the calculations are shown in Table 8. At temperatures below the range shown in Table 8, the thermal conductivity was assumed equal to the value at the lowest temperature specified.

Some of the results of the calculations that were made are shown in Fig. 11. A thermal gradient of approximately $25^{\circ} \mathrm{F} / \mathrm{in}$. is present in the radial direction in the ceramics. This should be added to the temperature differential imposed on the surfaces in evaluation of the thermal shock response of the ceramics during events such as loss of coolant, normal shutdown, and emergency shutdown. The magnitude of the thermal stresses can be estimated by

$\sigma \simeq E \alpha \Delta T /(1-\nu)$

If we assume that $E=34.5 \times 10^{3} \mathrm{MPa}\left(5 \times 10^{6} \mathrm{psi}\right)$ and $\alpha=1.8 \times 10^{-6} /{ }^{\circ} \mathrm{C}\left(10^{-6} /{ }^{\circ} \mathrm{F}\right)$, an instantaneous

\begin{tabular}{|c|c|c|}
\hline Material & $\begin{array}{c}\text { Temperature } \\
\text { (F) }\end{array}$ & $\begin{array}{c}\text { Thermal } \\
\text { conductivity } \\
\text { (Btu in. } \mathrm{hr}^{-1} \mathrm{ft}^{-2}{ }^{\circ} \mathrm{F}^{-1} \text { ) }\end{array}$ \\
\hline $\mathrm{SiO}_{2}$ & $\begin{array}{r}300 \\
500 \\
800 \\
1000 \\
1300 \\
1600 \\
1800 \\
2000\end{array}$ & $\begin{array}{l}0.22 \\
0.24 \\
0.26 \\
0.27 \\
0.28 \\
0.29 \\
0.29 \\
0.30\end{array}$ \\
\hline $\mathrm{Al}_{2} \mathrm{O}_{3}$ & $\begin{array}{r}77 \\
572 \\
932 \\
1472\end{array}$ & $\begin{array}{r}255 \\
130 \\
81 \\
61\end{array}$ \\
\hline $\mathrm{Si}_{3} \mathrm{~N}_{4}$ & $\begin{array}{r}932 \\
2192\end{array}$ & $\begin{array}{l}148 \\
118\end{array}$ \\
\hline
\end{tabular}
temperature change of $1093^{\circ} \mathrm{C}\left(2000^{\circ} \mathrm{F}\right)$ can generate stresses on the order of $174 \mathrm{MPa}(20 \mathrm{ksi})$, which will 

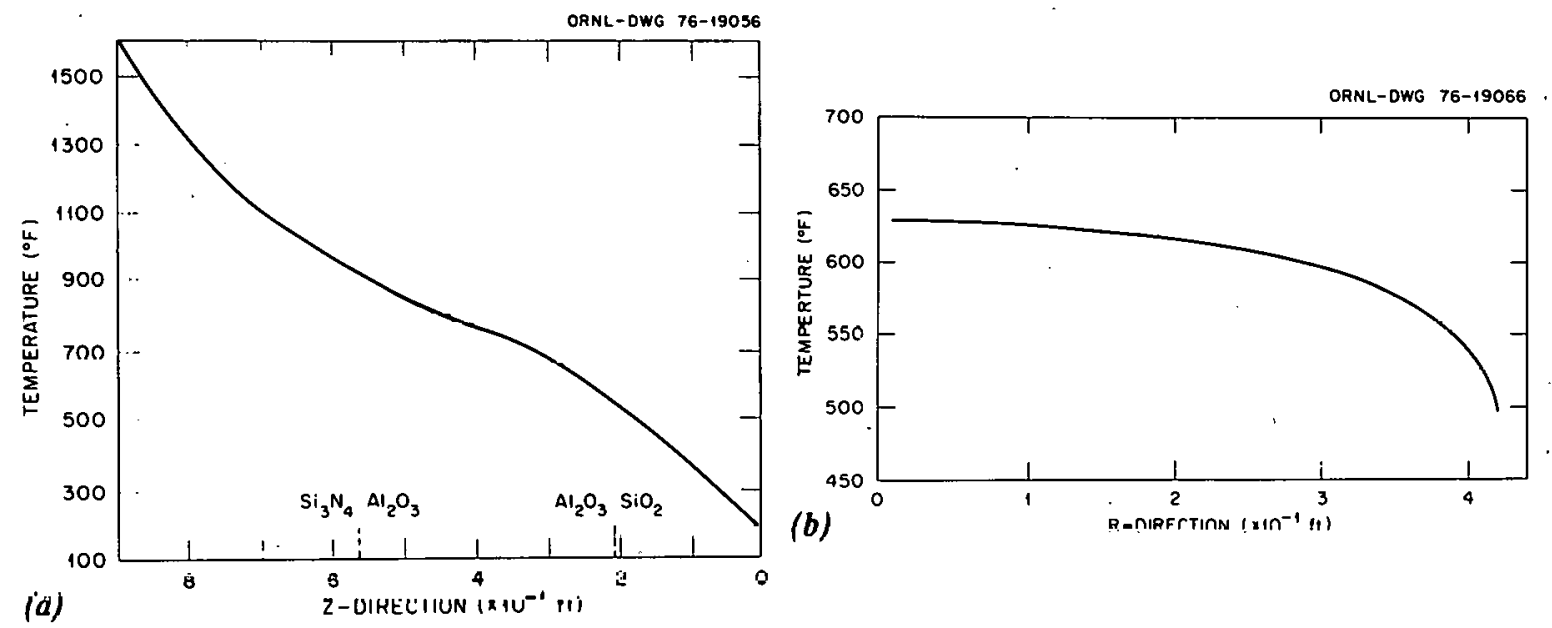

$$
\text { (a) }
$$
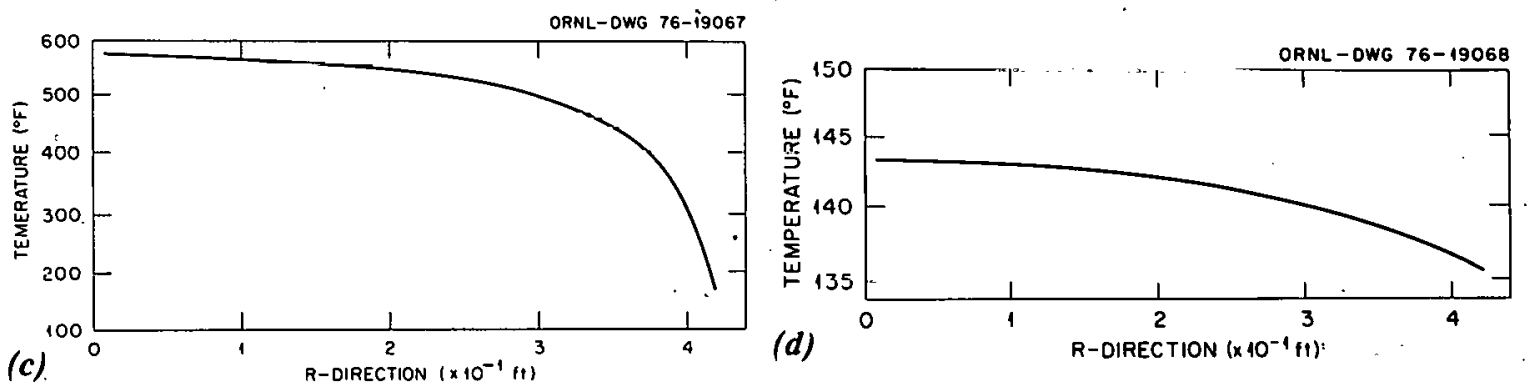

Fig. 11. Calculated temperature distributions in HTĞR structural ceramics under normal operatung còñitiónts. (a) Center-line temperature distribution, $(b)$ radial temperature distribution at the base of silicon nitride ceramic, $(c)$ radial temperature distribution at the base of alumina ceramic, $(d)$ radial temperature distribution at the base of fused silica.

cause failure in fused silica. A thermal gradient of $5.5^{\circ} \mathrm{C} / \mathrm{cm}\left(25^{\circ} \mathrm{F} / \mathrm{in}\right.$.) will generate stresses of up to 6.895 MPa (1000 psi). This is viewed as undesirable in terms of long-term structural stability.

More serious thermal shock effects will occur in the cases of start-up, loss of coulant, shutdown, and emergency shutdown.

Let us first consider heat-up of the HTGR core. The maximum heating ratc is given as $5.6^{\circ} \mathrm{C} / \mathrm{min}$ $\left(10^{\circ} \mathrm{F} / \mathrm{min}\right){ }^{45}$ If we assume that this rate is imposed on the structural ceramics, the stresses generated can be estimated ${ }^{40}$ by

$$
\sigma=\frac{E}{1-\nu} \cdot \frac{\phi \gamma_{m}^{2}}{3 K / \rho C_{p}}
$$

where $\phi$ is the heating or cooling rate, $\gamma_{m}$ is the half-thickness of the specimen, $\nu$ is the Polsson's rativ, and $K / \rho C_{p}$ is the thermal diffusivity of the ceramic. Assuming a half-thickness of $12.7 \mathrm{~cm}(5$ in.) and a

45. GASSAR6 (General Atomic Standard Safety Analysis Report) chaps. 4.4.2 and 4.4.3.

46. W. D. Kingery et al., Introduction to Ceramics, 2d ed., Wiley, New York, 1976, pp. 820-23. 
representative thermal diffusivity of $7.25 \mathrm{~cm}^{2} / \mathrm{sec}\left(28.1 \mathrm{ft}^{2} / \mathrm{hr}\right)$, the stress is on the order of $3.45 \mathrm{MPa}$ (500 psi). Stresses of this level probably will not cause any effects that would pose a safety hazard.

During shutdown or emergency shutdown operation, the core no longer generates heat, and the helium coolant will consequently have a lower temperature. For a relatively low heat transfer coefficient, the stress generated is ${ }^{46}$

$$
\sigma=0.31 \frac{\gamma_{m} h}{K} \cdot \frac{E a \Delta T}{(1-\nu)}
$$

where $h$ is the heat transfer coefficient, $\Delta T$ is the instantaneous temperature drop in the helium coolant, and the other parameters have been defined previously. If we use the following estimates: $\gamma_{m}=12.7 \mathrm{~cm}(5$ in.), $h=113 \mathrm{~W} \mathrm{~m}^{-2} K^{-1}\left(20 \mathrm{Btu} \mathrm{hr}{ }^{-1} \mathrm{ft}^{-2}{ }^{\circ} \mathrm{F}^{-1}\right), K=0.43 \mathrm{~W} \mathrm{~m}^{-1} K^{-1}$ (3 Btu in. $\left.\mathrm{ft}^{-2} \mathrm{hr}^{-1}{ }^{\circ} \mathrm{F}^{-1}\right)$, Eq. (33) shows that the requirement for $\sigma$ to be less than $345 \mathrm{MPa}(50 \mathrm{ksi})$ would force $\Delta T$ to be less than $111^{\circ} \mathrm{C}\left(200^{\circ} \mathrm{F}\right)$. This means that to minimize internal stress generation in the ceramics the helium coolant temperature must not be decreased too rapidly. However, slow cooling rates might not be compatible with a rapid shutdown required in emergency conditions. The procedure for emergency shutdown needs to be analyzed as to its compatibility with the thermal shock resistance of the ceramic supports.

\subsection{Other Safety Considerations}

The thermal insulation and structural stability of the core support system depend on the proper design and selection of the three ceramic supports under each core support block. In the current design, increasing the number of graphite and ceramic supports per block to more than 3 would have the following effects: (1) Ceramics of smaller diameter can be used; the smaller ceramic components usually have higher strength than larger ones. (2) The probability of a complete failure which requires all the ceramic supports to fail is less. (3) Core weight would not be as evenly distributed on the support graphite and ceramics, because the number of posts that have significantly different lengths increases as the total number of posts increases. Items 1 and 2 are favorable, while item 3 is a negative factor. Considering all these effects, it still seems desirable to increase the number of supports per block in order to have a higher degree of safety in terms of structural stability.

Another safety concern is adequate proof testing of the procured ceramics. The purity, homogeneity, and surface finishing of commercial ceramics are generally not consistent or easily controllable. Therefore, high quality control and stringent proof testing of all ceramic members are highly desirable.

\section{CONCLUSIONS}

The conclusions on the safety status of HTGR structural ceramics are summarized as follows:

1. Creep deformation in silicon nitride ceramics appears to be acceptable if the grain-boundary impurities are properly controlled.

2. Very high purity alumina ceramics are satisfactory in terms of creep if the composition is properly controlled.

3. Creep and devitrification in fused silica are potential problems.

4. Silicon nitride is probably incompatible with the graphite seat under HTGR conditions. However, reactions between alumina and silicon nitride or fused silica will not influence the load-bearing and thermal insulation stability of the structural ceramic system. 
5. Static fatigue in silicon nitride, alumina, and fused silica can cause a reduction in their compressive strengths and, consequently, can result in a reduction in the design safety factor during service life.

6. Preliminary calculations indicate that the thermal shock resistances of silicon nitride, alumina, and fused silica may require that the instantaneous helium coolant temperature change be less than $111^{\circ} \mathrm{C}$ $\left(200^{\circ} \mathrm{F}\right)$ in normal start-up, normal shutdown, or emergency shutdown operations.

7. Evaluation of the present conceptual design should be made relative to possible alternatives, and justification should be based on experimental observation of materials properties. 
1-2. Central Research Library

3. Document Reference Section

4-13. Laboratory Records Department

14. Laboratory Records, ORNL RC

15. ORNL Patent Office

16. S. J. Ball

17. R. J. Beaver

18. R. A. Bradley

19. C. R. Brinkman

20. J. P. Callahan

21. D. A. Canonic

22. J. A. Conlin

23. D. A. Constanzo

24. J. H. Coobs

25. W. R. Corwin

26. J. E. Cunningham

27. F. C. Davis

28. J. H. DeVan

29-33. J. R. DiStefano

34. W. G. Dodge

35. R. G. Donnelly

36. B. C. Duggins

37. W. P. Eatherly

38. G. G. Fee

39. Uri Gat

40. J. C. Griess, Jr.

41. A. G. Grindell

42. P. A. Hass

43-45. M. R. Hill

46. F. J. Homan

47. D. R. Johnson

48. M. J. Kania

49. P. R. Kasten

50. J. F. King

51. W. J. Lackey

52. K. H. Lin
53. T. B. Lindemer

54. A. L. Lotts

55. A. P. Malinauskas

56. H. E. McCoy

57. C. J. McHargue

58. C. S. Morgan

59. R. K. Nanstad

60. A. R. Olsen

61. A. E. Pasto

62. S. Peterson

63. H. Postma

64. P. L. Rittenhouse

65. J. M. Robbins

66. J. P. Sanders

67. A. C. Schaffhauser

68. J. L. Scott

69. J. H. Shaffer

70. R. L. Shepard

71. G. M. Slaughter

72. J. W. Snider

73. R. S. Stone

74. J. P. Strizak

75. V. J. Tennery

76. D. B. Trauger

77. V. C. A. Vaughan

78-85. G. C. Wei

86. J. R. Weir, Jr.

87. G. D. Whitman

88. R. P. Wichner

89. R. W. Balluffi (consultant)

90. P. M. Brister (consultant)

91. W. R. Hibbard, Jr. (consultant)

92. Hayne Palmour III (consultant)

93. N. E. Promisel (consultant)

94. D. F. Stein (consultant) 
95-98. ERDA DIVISION OF WASTE MANAGEMENT, PRODUCTION AND REPROCESSING, Washington, DC 20545

Acting Assistant Director for Reprocessing

Chief, Industrial Programs Branch

Chief, Projects Branch

Chief, Technology Branch

99-100. ERDA DIVISION OF REACTOR NUCLEAR RESEARCH. AND APPLICATIONS, Washington, DC 20545 .

Director

101-102. ERDA IDAHO OPERATIONS OFFICE, P.O. Box 2108, Idaho Falls, ID 83401

C. E. Willianıs, Manager*

Barry Smith*

103. ERDA OFFICE OF PROGRAM MANAGEMENT, RESEARCH AND SPACE PROGRAMS, P.O. Box 81325, San Diego, CA 92138

J. B. Radcliffe*

104. ERDA SAN FRANCISCO OPERATIONS OFFICE, 1333 Broadway, Wells Fargo Bldg., Oakland, CA 94612

R. D. Thorne, Manager*

105-107. ERDA OAK RIDGE OPERATIONS OFFICE, P.O. Box E, Oak Ridge, TN 37830

Director, Research and Technical Support Division

Director, Reactor Division

F. E. Dearing, Reactor Division*

108-284. ERDA TECHNICAL INFORMATION CENTER, P.O. Box 62, Oak Ridge, TN 37830

For distribution as shown in TID-4500 Distribution Category, UC.77 - Gas-Cooled Reactor Technology

*Not to be included in 100 limitation of internal copies. 